OPEN ACCESS

Edited by:

Marja Tiirola,

University of Jyväskylä, Finland

Reviewed by:

Kim Yrjälä,

University of Helsinki, Finland Julien Tremblay,

National Research Council Canada

(CNRC), Canada

*Correspondence:

Jianwen Zou

jwzou21@njau.edu.cn

Specialty section This article was submitted to Terrestrial Microbiology, a section of the journal

Frontiers in Microbiology

Received: 05 December 2016

Accepted: 27 February 2017

Published: 20 March 2017

Citation:

Li S, Song L, Gao X, Jin Y, Liu S,

Shen Q and Zou J (2017) Microbial Abundances Predict Methane and Nitrous Oxide Fluxes from a Windrow

Composting System.

Front. Microbiol. 8:409.

doi: 10.3389/fmicb.2017.00409

\section{Microbial Abundances Predict Methane and Nitrous Oxide Fluxes from a Windrow Composting System}

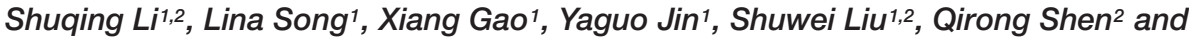 \\ Jianwen Zou',2*
}

1 Jiangsu Key Laboratory of Low Carbon Agriculture and GHGs Mitigation, College of Resources and Environmental Sciences, Nanjing Agricultural University, Nanjing, China, ${ }^{2}$ Jiangsu Key Laboratory and Engineering Center for Solid Organic Waste Utilization, Jiangsu Collaborative Innovation Center for Solid Organic Waste Resource Utilization, Nanjing Agricultural University, Nanjing, China

Manure composting is a significant source of atmospheric methane $\left(\mathrm{CH}_{4}\right)$ and nitrous oxide $\left(\mathrm{N}_{2} \mathrm{O}\right)$ that are two potent greenhouse gases. The $\mathrm{CH}_{4}$ and $\mathrm{N}_{2} \mathrm{O}$ fluxes are mediated by methanogens and methanotrophs, nitrifying and denitrifying bacteria in composting manure, respectively, while these specific bacterial functional groups may interplay in $\mathrm{CH}_{4}$ and $\mathrm{N}_{2} \mathrm{O}$ emissions during manure composting. To test the hypothesis that bacterial functional gene abundances regulate greenhouse gas fluxes in windrow composting systems, $\mathrm{CH}_{4}$ and $\mathrm{N}_{2} \mathrm{O}$ fluxes were simultaneously measured using the chamber method, and molecular techniques were used to quantify the abundances of $\mathrm{CH}_{4}$-related functional genes (mcrA and pmoA genes) and $\mathrm{N}_{2} \mathrm{O}$-related functional genes (amoA, narG, nirK, nirS, norB, and nos $Z$ genes). The results indicate that changes in interacting physicochemical parameters in the pile shaped the dynamics of bacterial functional gene abundances. The $\mathrm{CH}_{4}$ and $\mathrm{N}_{2} \mathrm{O}$ fluxes were correlated with abundances of specific compositional genes in bacterial community. The stepwise regression statistics selected pile temperature, $\mathrm{mcrA}$ and $\mathrm{NH}_{4}{ }^{+}$together as the best predictors for $\mathrm{CH}_{4}$ fluxes, and the model integrating nirk, nos $Z$ with pmoA gene abundances can almost fully explain the dynamics of $\mathrm{N}_{2} \mathrm{O}$ fluxes over windrow composting. The simulated models were tested against measurements in paddy rice cropping systems, indicating that the models can also be applicable to predicting the response of $\mathrm{CH}_{4}$ and $\mathrm{N}_{2} \mathrm{O}$ fluxes to elevated atmospheric $\mathrm{CO}_{2}$ concentration and rising temperature. Microbial abundances could be included as indicators in the current carbon and nitrogen biogeochemical models.

Keywords: $\mathrm{CH}_{4}$, carbon and nitrogen biogeochemistry, $\mathrm{N}_{2} \mathrm{O}$, bacterial gene abundance, greenhouse gas, statistical model

\section{INTRODUCTION}

It is of great concern worldwide that gaseous emissions from management of organic solid waste contribute to regional and global-scale environmental processes, such as eutrophication, acidification, and climate change (Naylor et al., 2005; Hou et al., 2015; Owen and Silver, 2015; Pardo et al., 2015). Organic waste management has been identified as an 
important source of anthropogenic greenhouse gas (GHG) emissions, particularly methane $\left(\mathrm{CH}_{4}\right)$ and nitrous oxide $\left(\mathrm{N}_{2} \mathrm{O}\right)$ [Intergovernmental Panel on Climate Change (IPCC), 2006]. Global $\mathrm{CH}_{4}$ and $\mathrm{N}_{2} \mathrm{O}$ emissions contribute considerably to the radiative forcing of the atmosphere, as their global warming potentials are 298 and 25 times that of carbon dioxide $\left(\mathrm{CO}_{2}\right)$ on mass basis over the 100-year time horizon, respectively [Intergovernmental Panel on Climate Change (IPCC), 2013]. Manures from livestock production account for $30-50 \%$ of the global agricultural $\mathrm{N}_{2} \mathrm{O}$ emissions and $12-41 \%$ of the total agricultural $\mathrm{CH}_{4}$ emissions for most countries (Oenema and Tamminga, 2005; Chadwick et al., 2011).

Manure composting is an alternative agricultural strategy for organic waste management that produces organic fertilizer to improve soil structure and fertility in croplands (Larney and Hao, 2007). The $\mathrm{CH}_{4}$ and $\mathrm{N}_{2} \mathrm{O}$ fluxes from manure composting have been studied extensively, contributing to a comprehensive assessment of $\mathrm{CH}_{4}$ and $\mathrm{N}_{2} \mathrm{O}$ emissions from manure composting worldwide [Czepiel et al., 1996; Hao et al., 2001; Intergovernmental Panel on Climate Change (IPCC), 2006; Xu et al., 2007; Mulbry and Ahn, 2014; Jiang et al., 2015; Pardo et al., 2015]. Yet, little is known about the interaction between pile physicochemical parameters and bacterial community, which has a key role in $\mathrm{CH}_{4}$ and $\mathrm{N}_{2} \mathrm{O}$ emissions from manure composting (Sharma et al., 2011; Angnes et al., 2013; Zhang et al., 2015). In particular, few studies have simultaneously focused on quantitative analysis of bacterial community composition and $\mathrm{CH}_{4}$ and $\mathrm{N}_{2} \mathrm{O}$ fluxes from composting manure (Maeda et al., 2010a,b; Chen et al., 2014; Zhang et al., 2015). Comparative quantitative analysis of specific bacterial functional groups and their interplay in $\mathrm{CH}_{4}$ and $\mathrm{N}_{2} \mathrm{O}$ emissions during manure composting are still limited.

To date, genes encoding enzymes involved in $\mathrm{CH}_{4}$ and $\mathrm{N}_{2} \mathrm{O}$ emissions have been targets of choice for studies focusing on functional groups of bacteria. This focus is fundamental for understanding mechanisms of carbon and nitrogen biogeochemistry and strategies for GHGs mitigation (Hu et al., 2015). Morales et al. (2010) illustrated denitrifying gene abundances as proxies for predicting $\mathrm{N}_{2} \mathrm{O}$ emissions from soils as a response to different long-term land management regimes. Regan et al. (2011) found the evidence that differences in microbial abundances can help explain enhanced $\mathrm{N}_{2} \mathrm{O}$ emissions in permanent grasslands under elevated atmospheric carbon dioxide. Nevertheless, a trade-off between $\mathrm{CH}_{4}$ and $\mathrm{N}_{2} \mathrm{O}$ fluxes has frequently been found in rice paddies and manure composting (Hou et al., 2001; Zou et al., 2005; Ahn et al., 2011; Shen et al., 2011; Mulbry and Ahn, 2014), simultaneous comparisons of the abundance of multiple $\mathrm{CH}_{4}$ - and $\mathrm{N}_{2} \mathrm{O}$-related genes and their interactions would be highly needed, especially when targeting functional bacteria to mitigate GHGs emission from agriculture (Hu et al., 2015).

Manure composting system is suggested as a good study model to examine the role of microbial abundances in shaping dynamics of $\mathrm{CH}_{4}$ and $\mathrm{N}_{2} \mathrm{O}$ fluxes due to their sensitive responses to changes in pile physicochemical properties, nitrogen transformation, and organic carbon decomposition during composting (Chadwick et al., 2011). Methane is produced by methanogenic organisms during the anaerobic degradation of organic materials; and the final key step, being reduction of $\mathrm{CO}_{2}$ using $\mathrm{H}_{2}$ to generate $\mathrm{CH}_{4}$, is catalyzed by methyl-coenzyme $\mathrm{M}$ reductase (MCR, EC 2.8.4.1) (Kim et al., 2008). The highly conserved morA gene encoding the $\alpha$-subunit of MCR has been widely used for analysis and quantification of methanogen communities (Pereyra et al., 2010; Sonoki et al., 2013). The generated $\mathrm{CH}_{4}$ could be oxidized to methanol with the catalysis of particulate membrane bound methane monooxygenase (EC 1.14.13.25) (Xin et al., 2004). The pmoA gene encoding the $\alpha$-subunit is widely used as the indicator for quantification of the methanotrophs from environmental samples (Wasmund et al., 2009; Sharma et al., 2011). The $\mathrm{CH}_{4}$ flux is the net outcome and combined action of methanogen and methanotrophs that are closely related to changes in physicochemical parameters and environmental factors during manure composting process (Sonoki et al., 2013).

During manure composting, $\mathrm{NH}_{4}{ }^{+}$generated from amino acids can be oxidized to $\mathrm{NO}_{2}{ }^{-}$by ammonia-oxidizing archaea and bacteria ( $\mathrm{AOA}$ and $\mathrm{AOB}$, respectively), through ammonia monooxygenase (EC 1.14.99.39, encoding by amoA) and hydroxylamine oxidoreductase. A part of the $\mathrm{NO}_{2}{ }^{-}$could be oxidized to $\mathrm{NO}_{3}{ }^{-}$by nitrite-oxidizing bacteria (NOB) (Maeda et al., 2011). Bacterial denitrification is a biochemical reaction where oxidized forms of nitrogen, including nitrate, nitrite, nitric oxide, and nitrous oxide, are gradually reduced (Wang et al., 2013). The four steps are generally catalyzed by nitrate reductase (encoding by narG), nitrite reductase (nirS/nirK), nitric oxide reductase (nor B), and nitrous oxide reductase (nos $Z$ ) (Maeda et al., 2011). Eventually, the $\mathrm{N}_{2} \mathrm{O}$ emission is a result of dynamic balance between $\mathrm{N}_{2} \mathrm{O}$ production and consumption. In addition, given that a trade-off between $\mathrm{CH}_{4}$ and $\mathrm{N}_{2} \mathrm{O}$ fluxes has been well documented in windrow composting systems (Hao et al., 2001; Zou et al., 2005; Ahn et al., 2011; Shen et al., 2011; Mulbry and Ahn, 2014), some compositional bacterial genes could be multifunctional as proxies for indicating dynamics of $\mathrm{CH}_{4}$ and $\mathrm{N}_{2} \mathrm{O}$ fluxes during windrow composting.

We conducted an in situ measurement of $\mathrm{CH}_{4}$ and $\mathrm{N}_{2} \mathrm{O}$ fluxes from a commercial composting windrow. Molecular techniques were used to quantify the abundances of $\mathrm{CH}_{4}{ }^{-}$and $\mathrm{N}_{2} \mathrm{O}$-related functional genes. The main objective of this study is to examine whether bacterial gene abundances can indicate dynamics of $\mathrm{CH}_{4}$ and $\mathrm{N}_{2} \mathrm{O}$ fluxes during windrow composting. Specifically, we aimed to test three general hypotheses. The first hypothesis stated that changes in pile physicochemical parameters would shape diverse time course patterns of bacterial functional genes abundance during windrow composting, given that bacterial community response variables are sensitive to environmental change. Second, we predicted that some specific physicochemical parameters and compositional bacterial enzymes encoded by relevant genes would be multifunctional as involved both in $\mathrm{CH}_{4}$ and $\mathrm{N}_{2} \mathrm{O}$ due to a trade-off between $\mathrm{CH}_{4}$ and $\mathrm{N}_{2} \mathrm{O}$ fluxes during windrow composting. Eventually, as both production and consumption of $\mathrm{CH}_{4}$ and $\mathrm{N}_{2} \mathrm{O}$ are controlled by the interplay of enzyme encoding bacterial functional genes, we hypothesized that bacterial functional gene abundances could be used as proxies for indicating dynamics of $\mathrm{CH}_{4}$ and $\mathrm{N}_{2} \mathrm{O}$ fluxes during windrow composting. 
TABLE 1 | The primers used for quantitative PCR in this study.

\begin{tabular}{|c|c|c|c|c|c|c|}
\hline Gene & Name & Sequence & Thermal profile & No. cycles & Product size & Reference \\
\hline \multirow[t]{2}{*}{$m c r A$} & mlas & GGTGGTGTMGGDTTCACMCARTA & $\begin{array}{l}30 \mathrm{~s}-95^{\circ} \mathrm{C}, 95^{\circ} \mathrm{C}-15 \mathrm{~s}, 55^{\circ} \mathrm{C}-30 \mathrm{~s}, 72^{\circ} \mathrm{C}-30 \mathrm{~s} \\
80^{\circ} \mathrm{C}-30 \mathrm{~s}\end{array}$ & 1 & 509 bp & $\begin{array}{l}\text { Steinberg and } \\
\text { Regan, } 2009\end{array}$ \\
\hline & mcr-rev & CGTTCATBGCGTAGTTVGGRTAGT & $\begin{array}{l}95^{\circ} \mathrm{C}-5 \mathrm{~s}, 60^{\circ} \mathrm{C}-34 \mathrm{~s}, 72^{\circ} \mathrm{C}-15 \mathrm{~s} 95^{\circ} \mathrm{C}-15 \mathrm{~s} \\
55^{\circ} \mathrm{C}-30 \mathrm{~s}, 72^{\circ} \mathrm{C}-30 \mathrm{~s}, 80^{\circ} \mathrm{C}-30 \mathrm{~s}\end{array}$ & 40 & & \\
\hline \multirow[t]{2}{*}{$p m o A$} & pmoA189-f & GGNGACTGGGACTTCTGG & $\begin{array}{l}30 \mathrm{~s}-95^{\circ} \mathrm{C}, 95^{\circ} \mathrm{C}-15 \mathrm{~s}, 55^{\circ} \mathrm{C}-30 \mathrm{~s}, 72^{\circ} \mathrm{C}-30 \mathrm{~s} \\
80^{\circ} \mathrm{C}-30 \mathrm{~s}\end{array}$ & 1 & 472 bp & $\begin{array}{l}\text { Costello and } \\
\text { Lidstrom, } 1999\end{array}$ \\
\hline & mb661-r & CCGGMGCAACGTCYTTACC & $\begin{array}{l}95^{\circ} \mathrm{C}-5 \mathrm{~s}, 60^{\circ} \mathrm{C}-34 \mathrm{~s}, 72^{\circ} \mathrm{C}-15 \mathrm{~s} 95^{\circ} \mathrm{C}-15 \mathrm{~s} \\
55^{\circ} \mathrm{C}-30 \mathrm{~s}, 72^{\circ} \mathrm{C}-30 \mathrm{~s}, 80^{\circ} \mathrm{C}-30 \mathrm{~s}\end{array}$ & 40 & & \\
\hline \multirow[t]{2}{*}{ amoA } & amoA-1F & GGGGTITCTACTGGTGGT & $\begin{array}{l}30 \mathrm{~s}-95^{\circ} \mathrm{C}, 95^{\circ} \mathrm{C}-15 \mathrm{~s}, 55^{\circ} \mathrm{C}-30 \mathrm{~s}, 72^{\circ} \mathrm{C}-30 \mathrm{~s} \\
80^{\circ} \mathrm{C}-30 \mathrm{~s}\end{array}$ & 1 & $491 \mathrm{bp}$ & $\begin{array}{l}\text { Rotthauwe } \\
\text { et al., } 1997\end{array}$ \\
\hline & $a m o A-2 R$ & CCCCTCKGSAAAGCCTTCTTC & $\begin{array}{l}95^{\circ} \mathrm{C}-5 \mathrm{~s}, 55^{\circ} \mathrm{C}-34 \mathrm{~s}, 72^{\circ} \mathrm{C}-15 \mathrm{~s} 95^{\circ} \mathrm{C}-15 \mathrm{~s} \\
55^{\circ} \mathrm{C}-30 \mathrm{~s}, 72^{\circ} \mathrm{C}-30 \mathrm{~s}, 80^{\circ} \mathrm{C}-30 \mathrm{~s}\end{array}$ & 40 & & \\
\hline \multirow[t]{2}{*}{ narG } & narG-1960m2f & TAYGTSGGGCAGGARAAACTG & $\begin{array}{l}30 \mathrm{~s}-95^{\circ} \mathrm{C}, 95^{\circ} \mathrm{C}-15 \mathrm{~s}, 55^{\circ} \mathrm{C}-30 \mathrm{~s}, 72^{\circ} \mathrm{C}-30 \mathrm{~s} \\
80^{\circ} \mathrm{C}-30 \mathrm{~s}\end{array}$ & 1 & $110 \mathrm{bp}$ & $\begin{array}{l}\text { López-Gutiérrez } \\
\text { et al., } 2004\end{array}$ \\
\hline & narG-2050m2r & CGTAGAAGAAGCTGGTGCTGTT & $\begin{array}{l}95^{\circ} \mathrm{C}-5 \mathrm{~s}, 60^{\circ} \mathrm{C}-34 \mathrm{~s}, 72^{\circ} \mathrm{C}-15 \mathrm{~s} 95^{\circ} \mathrm{C}-15 \mathrm{~s} \\
55^{\circ} \mathrm{C}-30 \mathrm{~s}, 72^{\circ} \mathrm{C}-30 \mathrm{~s}, 80^{\circ} \mathrm{C}-30 \mathrm{~s}\end{array}$ & 40 & & \\
\hline \multirow[t]{2}{*}{ nirs } & nirSCd3aF & TACCACCCSGARCCGCGCGT & $\begin{array}{l}30 \mathrm{~s}-95^{\circ} \mathrm{C}, 95^{\circ} \mathrm{C}-15 \mathrm{~s}, 55^{\circ} \mathrm{C}-30 \mathrm{~s}, 72^{\circ} \mathrm{C}-30 \mathrm{~s} \\
80^{\circ} \mathrm{C}-30 \mathrm{~s}\end{array}$ & 1 & $425 \mathrm{bp}$ & $\begin{array}{l}\text { Braker et al., } \\
1998\end{array}$ \\
\hline & nirSR3cd & GCCGCCGTCRTGVAGGAA & $\begin{array}{l}95^{\circ} \mathrm{C}-5 \mathrm{~s}, 58^{\circ} \mathrm{C}-34 \mathrm{~s}, 72^{\circ} \mathrm{C}-15 \mathrm{~s} 95^{\circ} \mathrm{C}-15 \mathrm{~s} \\
55^{\circ} \mathrm{C}-30 \mathrm{~s}, 72^{\circ} \mathrm{C}-30 \mathrm{~s}, 80^{\circ} \mathrm{C}-30 \mathrm{~s}\end{array}$ & 40 & & \\
\hline \multirow[t]{2}{*}{ nirk } & nirkF1aCu & ATCATGGTSCTGCCGCG & $\begin{array}{l}30 \mathrm{~s}-95^{\circ} \mathrm{C}, 95^{\circ} \mathrm{C}-15 \mathrm{~s}, 55^{\circ} \mathrm{C}-30 \mathrm{~s}, 72^{\circ} \mathrm{C}-30 \mathrm{~s} \\
80^{\circ} \mathrm{C}-30 \mathrm{~s}\end{array}$ & 1 & $473 \mathrm{bp}$ & $\begin{array}{l}\text { Henry et al., } \\
2004\end{array}$ \\
\hline & nirkR3Cu & GCCTCGATCAGRTTGTGGTT & $\begin{array}{l}95^{\circ} \mathrm{C}-5 \mathrm{~s}, 58^{\circ} \mathrm{C}-34 \mathrm{~s}, 72^{\circ} \mathrm{C}-15 \mathrm{~s} 95^{\circ} \mathrm{C}-15 \mathrm{~s} \\
55^{\circ} \mathrm{C}-30 \mathrm{~s}, 72^{\circ} \mathrm{C}-30 \mathrm{~s}, 80^{\circ} \mathrm{C}-30 \mathrm{~s}\end{array}$ & 40 & & \\
\hline \multirow[t]{2}{*}{ norB } & qnorB2F & GGNCAYCARGGNTAYGA & $\begin{array}{l}30 \mathrm{~s}-95^{\circ} \mathrm{C}, 95^{\circ} \mathrm{C}-15 \mathrm{~s}, 55^{\circ} \mathrm{C}-30 \mathrm{~s}, 72^{\circ} \mathrm{C}-30 \mathrm{~s} \\
80^{\circ} \mathrm{C}-30 \mathrm{~s}\end{array}$ & 1 & 262 bp & $\begin{array}{l}\text { Braker and } \\
\text { Tiedje, } 2003\end{array}$ \\
\hline & qnorB5R & ACCCANAGRTGNACNACCCACCA & $\begin{array}{l}95^{\circ} \mathrm{C}-5 \mathrm{~s}, 60^{\circ} \mathrm{C}-34 \mathrm{~s}, 72^{\circ} \mathrm{C}-15 \mathrm{~s} 95^{\circ} \mathrm{C}-15 \mathrm{~s} \\
55^{\circ} \mathrm{C}-30 \mathrm{~s}, 72^{\circ} \mathrm{C}-30 \mathrm{~s}, 80^{\circ} \mathrm{C}-30 \mathrm{~s}\end{array}$ & 40 & & \\
\hline \multirow[t]{2}{*}{$\operatorname{nos} Z$} & nosZ-F & AGAACGACCAGCTGATCGACA & $\begin{array}{l}30 \mathrm{~s}-95^{\circ} \mathrm{C}, 95^{\circ} \mathrm{C}-15 \mathrm{~s}, 55^{\circ} \mathrm{C}-30 \mathrm{~s}, 72^{\circ} \mathrm{C}-30 \mathrm{~s} \\
80^{\circ} \mathrm{C}-30 \mathrm{~s}\end{array}$ & 1 & 300 bp & $\begin{array}{l}\text { Scala and } \\
\text { Kerkhof, } 1998\end{array}$ \\
\hline & nosZ-R & TCCATGGTGACGCCGTGGTTG & $\begin{array}{l}95^{\circ} \mathrm{C}-5 \mathrm{~s}, 60^{\circ} \mathrm{C}-34 \mathrm{~s}, 72^{\circ} \mathrm{C}-15 \mathrm{~s} 95^{\circ} \mathrm{C}-15 \mathrm{~s} \\
55^{\circ} \mathrm{C}-30 \mathrm{~s}, 72^{\circ} \mathrm{C}-30 \mathrm{~s}, 80^{\circ} \mathrm{C}-30 \mathrm{~s}\end{array}$ & 40 & & \\
\hline
\end{tabular}

$M=A / C, D=A / G / T, R=A / G, B=C / G / T, V=G / A / C, N=A / C / G / T, Y=C / T, K=G / T, S=G / C$.

TABLE 2 | Changes of physicochemical parameters (mean $\pm \mathrm{SE}, n=3$ ) during windrow dairy manure composting.

\begin{tabular}{|c|c|c|c|c|c|c|c|c|c|}
\hline Days & Temperature $\left({ }^{\circ} \mathbf{C}\right)$ & Moisture (\%) & $\mathrm{pH}$ & SOC (\%) & TN (\%) & $\mathrm{C} / \mathrm{N}$ & $\begin{array}{c}\mathrm{NH}_{4}^{+} \\
\left(\mathbf{g} \cdot \mathbf{k g}^{-1} \mathrm{DM}\right)\end{array}$ & $\begin{array}{c}\mathrm{NO}_{3}^{-} \\
\left(\mathbf{g} \cdot \mathbf{k g}^{-1} \mathrm{DM}\right)\end{array}$ & $\begin{array}{c}\mathrm{NO}_{2}^{-} \\
\left(\mathrm{mg} \cdot \mathrm{kg}^{-1} \mathrm{DM}\right)\end{array}$ \\
\hline 2 & $44.7 \pm 0.1$ & $60.1 \pm 0.9$ & $8.15 \pm 0.18$ & $23.7 \pm 0.3$ & $1.45 \pm 0.11$ & $16.4 \pm 1.3$ & $2.40 \pm 0.29$ & $0.37 \pm 0.02$ & $1.89 \pm 0.10$ \\
\hline 6 & $67.7 \pm 0.3$ & $52.1 \pm 1.4$ & $8.34 \pm 0.03$ & $21.3 \pm 1.0$ & $1.35 \pm 0.09$ & $15.7 \pm 0.2$ & $1.40 \pm 0.09$ & $0.40 \pm 0.03$ & $1.73 \pm 0.05$ \\
\hline 10 & $68.0 \pm 0.1$ & $48.0 \pm 1.2$ & $8.10 \pm 0.03$ & $22.6 \pm 0.3$ & $1.35 \pm 0.01$ & $16.7 \pm 0.2$ & $1.34 \pm 0.58$ & $0.36 \pm 0.01$ & $1.60 \pm 0.06$ \\
\hline 16 & $65.4 \pm 0.3$ & $48.5 \pm 1.4$ & $8.06 \pm 0.10$ & $22.2 \pm 0.7$ & $1.42 \pm 0.05$ & $15.7 \pm 1.1$ & $2.02 \pm 0.01$ & $0.32 \pm 0.01$ & $1.26 \pm 0.08$ \\
\hline 46 & $55.5 \pm 0.0$ & $16.5 \pm 0.8$ & $8.11 \pm 0.01$ & $21.5 \pm 0.2$ & $1.56 \pm 0.06$ & $13.8 \pm 0.6$ & $1.49 \pm 0.02$ & $0.36 \pm 0.00$ & $1.51 \pm 0.25$ \\
\hline 52 & $49.6 \pm 0.1$ & $21.4 \pm 0.5$ & $8.12 \pm 0.03$ & $20.8 \pm 0.6$ & $1.63 \pm 0.01$ & $12.7 \pm 0.3$ & $1.38 \pm 0.05$ & $0.38 \pm 0.04$ & $1.60 \pm 0.23$ \\
\hline 55 & $48.1 \pm 0.0$ & $18.9 \pm 1.7$ & $8.02 \pm 0.02$ & $20.4 \pm 0.6$ & $1.63 \pm 0.05$ & $12.5 \pm 0.1$ & $0.99 \pm 0.06$ & $0.46 \pm 0.03$ & $1.49 \pm 0.14$ \\
\hline 61 & $46.0 \pm 0.1$ & $13.5 \pm 0.0$ & $8.16 \pm 0.02$ & $21.4 \pm 0.2$ & $1.61 \pm 0.01$ & $13.3 \pm 0.2$ & $1.09 \pm 0.21$ & $0.34 \pm 0.00$ & $1.59 \pm 0.08$ \\
\hline 65 & $45.2 \pm 0.2$ & $23.7 \pm 0.0$ & $7.99 \pm 0.04$ & $20.8 \pm 0.0$ & $1.65 \pm 0.03$ & $12.6 \pm 0.3$ & $1.27 \pm 0.21$ & $0.33 \pm 0.02$ & $2.09 \pm 0.09$ \\
\hline
\end{tabular}

\section{MATERIALS AND METHODS}

\section{Windrow Composting Construction}

The windrow composting experiment was carried out in a commercial organic fertilizer company (Jiangyin Lianye
Biological Science and Technology Co., Ltd.), located at Wuxi, Jiangsu province, China. The experiment was initiated on April 26 and completed on June 29, 2014 (65 days). Three replicate commercial-scale compost piles were constructed using a mixture of dairy manure solids and straw bedding with a mixing ratio 
of $80 \%: 20 \%$ on a fresh weight basis. Sawdust used for dairy manure solids was obtained from scraped dairy manure with 75\% moisture in a local dairy feedlot. Chopped rice straw collected from local paddy rice fields was used as a bulking agent and a source of carbon. Uniform rectangle windrows were placed on individual platforms to enable determination of windrow mass values in an open-sided but roofed compost. The volume of each compost windrow was set up to be approximately $125 \mathrm{~m}^{3}$ (40 $\mathrm{m}$ in length, $2.8 \mathrm{~m}$ in width, and 1.1 in height). The composting process can be generally divided into two phases, namely, the bio-oxidative phase with mechanical turning for 25 days (Phase I, April 26 to May 20, 2014) and the cooling and maturing phase without pile turning for 40 days (Phase II, May 21 to June 29, 2014) (Chen et al., 2014). The windrow was mechanically turned using an astraddle compost turner once every 2 days during Phase I, and thereafter the compost piles were moved away for post-maturation without turning. Three compost windrows were treated as experimental replicates. Each windrow along its length was sub-divided into three sections that were treated as three parallel locations for substrate material and gas sampling.

\section{Measurement of $\mathrm{CH}_{4}$ and $\mathrm{N}_{2} \mathrm{O}$ Fluxes}

The fluxes of $\mathrm{CH}_{4}$ and $\mathrm{N}_{2} \mathrm{O}$ during compositing were simultaneously measured using vented chamber technique (Hao et al., 2001; Xin et al., 2004; Zou et al., 2005; Chen et al., 2014). Gas samples were taken once a week except supplementary sampling episodes as needed to capture high flux peaks. To stabilize the disturbance, PVC chamber collar bases $(30 \mathrm{~cm}$ length $\times 30 \mathrm{~cm}$ width $\times 25 \mathrm{~cm}$ height) were pre-inserted $25 \mathrm{~cm}$ into the pile 10-12 h before each gas sampling. The top edge of the collar base exhibits a groove $(5 \mathrm{~cm}$ in depth) that can be filled with water to seal the rim of the chamber during gas sampling. While taking gas samples, the opaque chamber $(30 \mathrm{~cm}$ length $\times 30 \mathrm{~cm}$ width $\times 50 \mathrm{~cm}$ height) was placed on the peak of each windrow with rim of the chamber fitted into the groove of collar. Gas samples were extracted from inside the chambers using $60-\mathrm{mL}$ plastic syringes fitted with three-way stopcocks at $0,5,10,20$, and $30 \mathrm{~min}$ after chamber closure and immediately injected into a $50 \mathrm{~mL}$ pre-evacuated Exetainer fitted with butyl rubber septa (Hao et al., 2001; Chen et al., 2014). Gas samples were taken between 0800 and 1000 LST on each sampling day, and they were transported to the laboratory for analysis by gas chromatograph (GC) within a few hours (Zou et al., 2009; Liu et al., 2010).

The mixing ratios of $\mathrm{CH}_{4}$ and $\mathrm{N}_{2} \mathrm{O}$ were analyzed with a modified GH (Agilent 7890) equipped with a flame ionization detector (FID) and an electron capture detector (ECD) (Zou et al., 2005; Liu et al., 2012). A non-linear fitting approach was adopted to determine the $\mathrm{CH}_{4}$ and $\mathrm{N}_{2} \mathrm{O}$ fluxes (Hao et al., 2001; Kroon et al., 2008; Chen et al., 2014). On each sampling day, mean of fluxes taken from three parallel sections within each windrow represent flux measurement of the sampling windrows. Average fluxes and standard deviations of $\mathrm{CH}_{4}$ and $\mathrm{N}_{2} \mathrm{O}$ were calculated from three replicate windrows. Accumulative $\mathrm{CH}_{4}$ and $\mathrm{N}_{2} \mathrm{O}$ emissions during compositing were sequentially

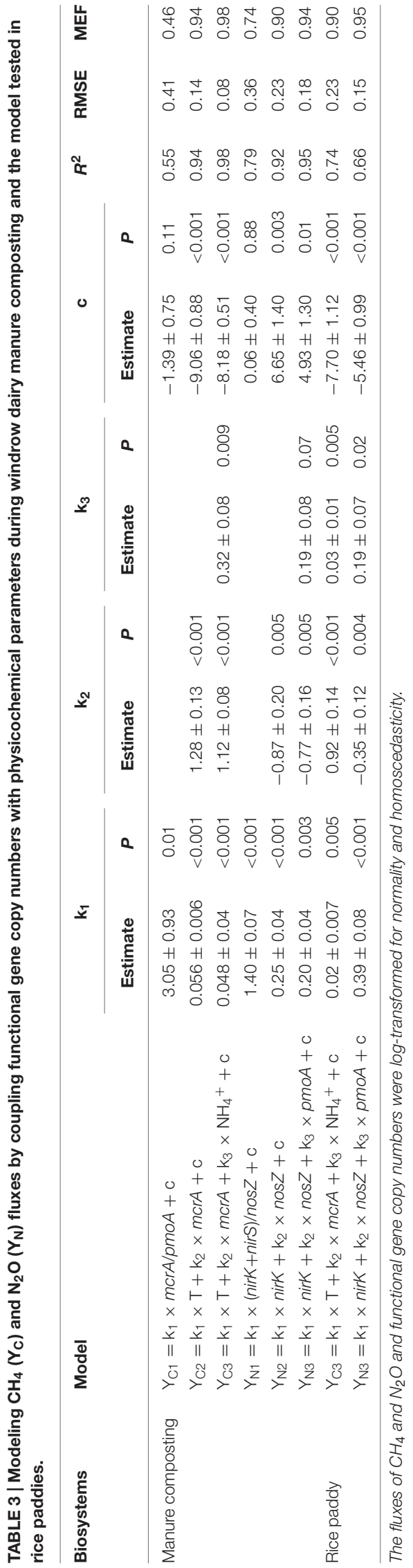




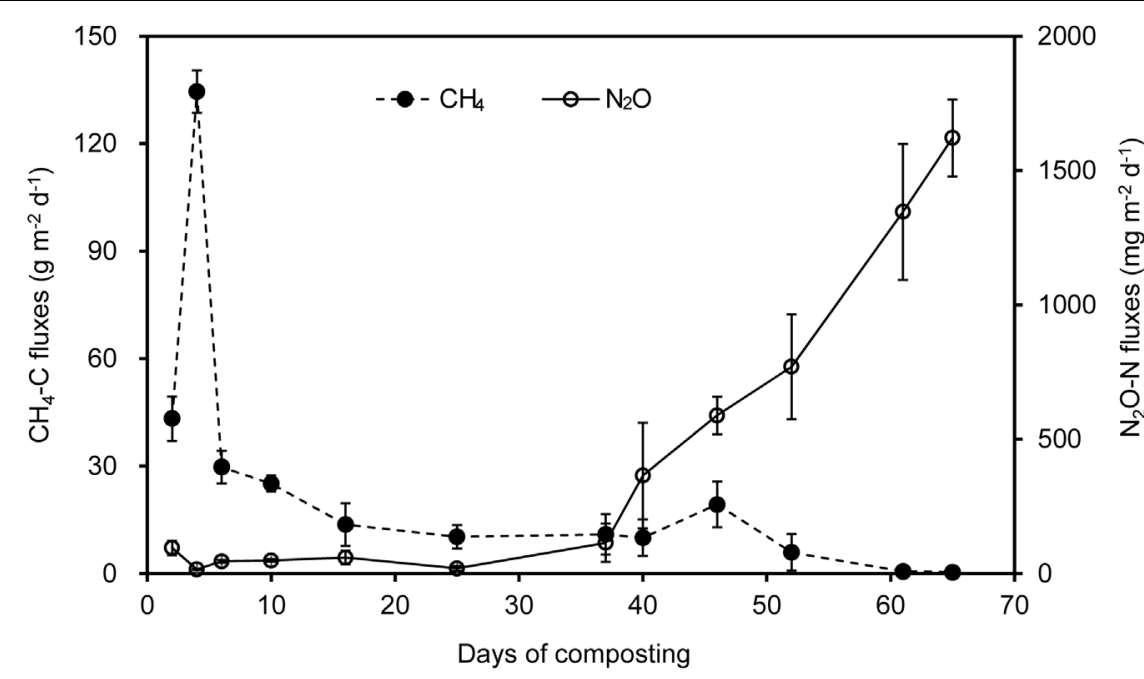

FIGURE 1 | Fluxes of $\mathbf{C H}_{4}$ and $\mathbf{N}_{2} \mathbf{O}$ during a 65 -day period of windrow dairy manure composting. Error bars show standard error of the mean of triplicate compost windrows.

accumulated from the fluxes between every two adjacent intervals of measurements (Zou et al., 2005; Liu et al., 2012).

\section{Real-Time Quantitative PCR (qPCR) Assays of the Functional Genes}

Real-time quantitative PCR (qPCR) was performed for investigation of the functional microbial community dynamics during the composting process (days 4, 10, 16, 25, 37, 46, 55, 61, and 65). The genes encoding the key enzymes involved in $\mathrm{CH}_{4}$ and $\mathrm{N}_{2} \mathrm{O}$ emissions included $\alpha$-subunit of methyl-coenzyme $\mathrm{M}$ reductase $(m c r A), \alpha$-subunit methane monooxygenase ( $p m o A)$, ammonia monooxygenase $(a m o A)$, nitrate reductase (narG), nitrite reductase (nirK and nirS), nitric oxide reductase (nor $B$ ), and nitrous oxide reductase (nos $Z$ ). The information of these functional genes and the using primers and conditions were referenced in Table 1. According to the manufacturer's instructions, DNA was extracted from the compost samples that stored at $-80^{\circ} \mathrm{C}$ using the UltraClean soil DNA isolation kit (Mo Bio, USA). Each DNA sample for next-analysis was the mixture of DNA extractions from three parallel sections within each windrow. The concentrations of DNA samples were determined by a Nanodrop (Thermo Scientific, USA). The amplified fragments for each functional gene based on different primers (Table 1) were cloned in pMD 18-T vector and sequenced, the correct clones corresponding to each functional gene were stepwise 10 -fold diluted for standard curve preparation. The qPCR amplifications were performed in a total volume of $20 \mu \mathrm{L}$ using a SYBR@Premix Ex Taq ${ }^{\mathrm{TM}}$ (Takara, China), with reaction mixture consisting of $10 \mu \mathrm{L}$ SYBR@Premix Ex Taq, $0.4 \mu \mathrm{L}$ each primer $^{\mathrm{TM}}\left(10 \mu \mathrm{mol} \mathrm{L}{ }^{-1}\right), 0.4 \mu \mathrm{L}$ ROX reference dye II $(50 \times)$, $2 \mu \mathrm{L}$ template DNA, and $6.8 \mu \mathrm{L}$ sterile water. Amplification was performed triplicate using 7500 System (ABI, USA). The detailed reaction conditions were listed in Table 1. Fluorescence normalization and data analysis were performed with 7500 Fast System SDS software (ABI, USA).

\section{Physicochemical Parameters Determination}

Windrow temperature was measured by inserting the mercury thermometers at $30 \mathrm{~cm}$ depth of the pile on each gas sampling day. To examine dynamics of physicochemical parameters of composting material, manure material samples were taken while gas flux sampling (Table 2). Samples were randomly collected from three longitudinal sections and mixture, generating approximately $300 \mathrm{~g}$ of subsamples. The collected samples were divided into three parts, two parts were immediately preserved at $4^{\circ} \mathrm{C}$ until analysis, while the other part was air-dried, passed through a $0.15 \mathrm{~mm}$ sieve, and stored in a desiccator as needed for further analysis. The moisture content of different fresh samples was determined by oven-drying to a constant weight at $105^{\circ} \mathrm{C}$. The $\mathrm{C} / \mathrm{N}$ ratio was calculated based on the total organic carbon (TOC) and total nitrogen (TN) contents that were determined by an auto elemental analyzer (Vario EL III, Elementar, Germany). For analysis of the water-soluble fractions of the composting material, the aqueous compost extracts were obtained by shaking of the mixture of $20 \mathrm{~g}$ of fresh sample with $200 \mathrm{~mL}$ distilled water $\left(1: 10 \mathrm{w} / \mathrm{v}\right.$ ratio) on a horizontal shaker at $25^{\circ} \mathrm{C}$, as described in Castaldi et al. (2008). The $\mathrm{pH}$ was performed on aqueous suspensions of the fresh samples $(1: 10, \mathrm{w} / \mathrm{v}$, compost/water ratio) using a $\mathrm{pH}$ electrode (PHS-3C mv/pH detector, Shanghai, China). The $\mathrm{NH}_{4}{ }^{+}-\mathrm{N}, \mathrm{NO}_{3}{ }^{-}-\mathrm{N}$, and $\mathrm{NO}_{2}{ }^{-}-\mathrm{N}$ of composting material were extracted with $100 \mathrm{ml} 2 \mathrm{M} \mathrm{KCl}$ solution at a ratio of 1:20 at $25^{\circ} \mathrm{C}$ and measured following the three wavelength ultraviolet spectrometry and indophenol blue method, using the ultraviolet spectrophotometer, respectively (HITACHI, U-2900, Japan).

\section{Statistical Analysis}

Physicochemical parameters data were expressed as means of replicates based on a dry weight of compost materials. A pairwise correlation was conducted for each pair of variables including 


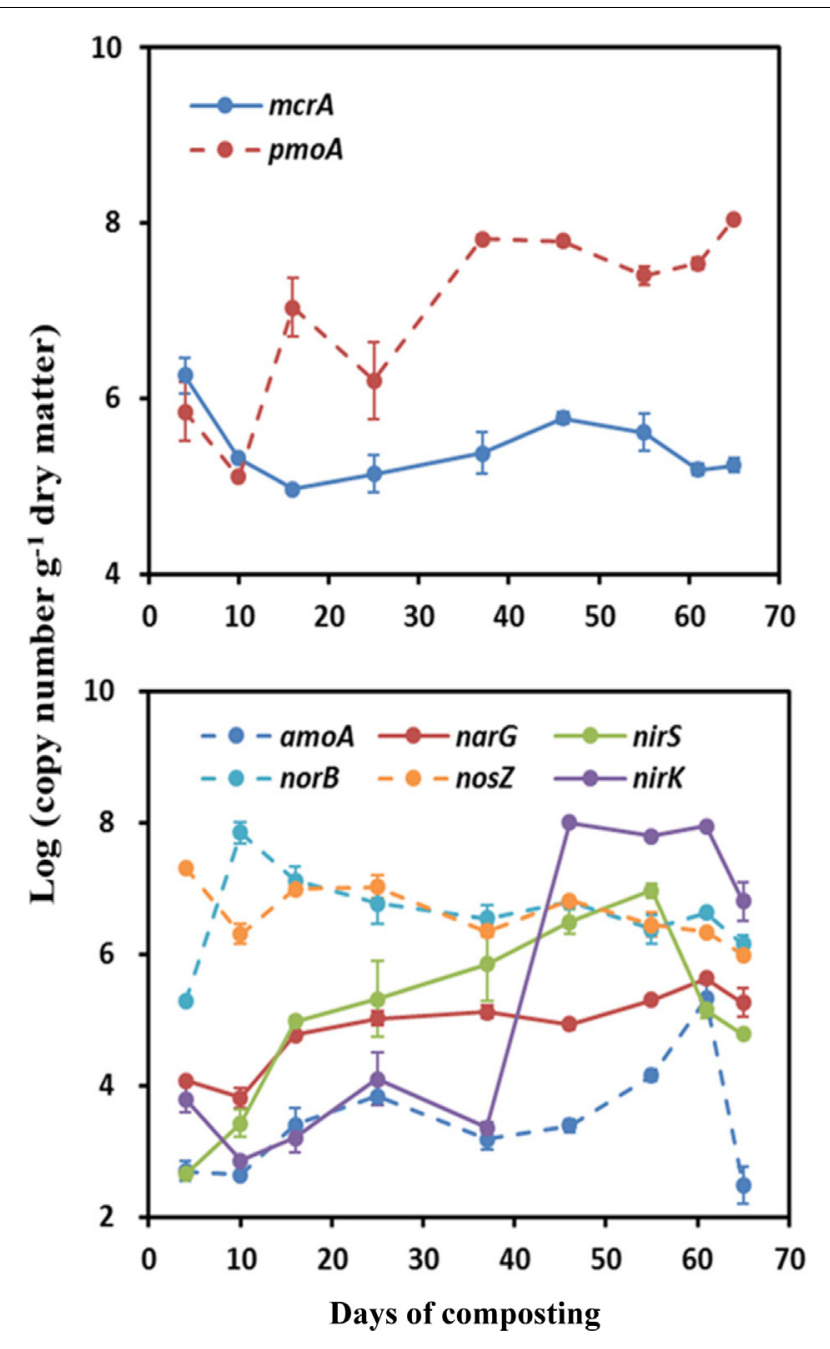

FIGURE 2 | Changes in functional gene copy numbers associated with $\mathrm{CH}_{4}$ and $\mathrm{N}_{2} \mathrm{O}$ emissions during windrow dairy manure composting.

Values indicate log-transformed gene copy numbers. Error bars show standard error of the mean of triplicate compost windrows.
$\mathrm{CH}_{4}$ and $\mathrm{N}_{2} \mathrm{O}$ fluxes, bacterial gene abundance copies, and physicochemical parameters. Bacterial gene abundance copies and $\mathrm{CH}_{4}$ and $\mathrm{N}_{2} \mathrm{O}$ fluxes were log-transformed for normality and homoscedasticity as needed in statistical analyses. A linear stepwise regression model with the personality of Ordinary Least Squares (OLS) was used to fit $\mathrm{CH}_{4}$ and $\mathrm{N}_{2} \mathrm{O}$ fluxes by bacterial gene abundance copies and physicochemical parameters. In this method, regression variables are randomly selected based on prior probability, and the randomly selected variables are further screened by stepwise forward regression. Eventually, the forms of model are updated accordingly (Table 3). A $t$-test was used to examine the statistical significance of parameter estimates in the simulated OLS model.

\section{Model Test in Rice Paddies under T-FACE}

To examine whether the simulated OLS models could also be applicable to other environmental systems, the models were tested against field measurements in paddy rice cropping systems under elevated atmospheric $\mathrm{CO}_{2}$ and rising temperature (a T-FACE platform). The field T-FACE platform was established in Kangbo village $\left(31^{\circ} 300 \mathrm{~N}, 120^{\circ} 330 \mathrm{E}\right)$, Guli Township, Changshu Municipality, Jiangsu, China, in 2010. The paddy field soil is a gleyic stagnic anthrosol formed on a clayey lacustrine deposit and cultivated under continuous rice-wheat rotation. The T-FACE platform had 12 octagonal plots, with the inner circle with an area of $25 \mathrm{~m}^{2}$ per plot. The experimental treatments included four experimental treatments with three replicates, namely, one with target atmospheric $\mathrm{CO}_{2}$ up to 500 ppmv $\left(\mathrm{CO}_{2}\right)$, one with warming of canopy temperature by $1.5-2.0^{\circ} \mathrm{C}$ above ambient $(\mathrm{T})$, and one with combined $\mathrm{CO}_{2}$ enrichment and warming $\left(\mathrm{CO}_{2}+\mathrm{T}\right)$, and taking an untreated plots with ambient condition as controls (Ambient). Seedlings of a local rice cultivar (Changyou 5) were transplanted into fields on June 20, 2014 and harvested on October 22, 2014. Spacing of hills was $15.3 \times 25.4 \mathrm{~cm}$ (equivalent to 25.7 hills $\mathrm{m}^{2}$ and resulting in a plant density of 77.1 plants $\mathrm{m}^{2}$ ) for each experimental plots. All the field plots were under a typical water regime of flooding-midseason drainage-refloodingmoisture irrigation during the rice-growing season. The design of T-FACE platform and field experimental treatments and agricultural practice were detailed in Liu et al. (2014), Cai et al. (2015), and Chen et al. (2016).

In rice paddies, gas flux measurements and soil samples for physicochemical properties and microbial genes abundance analyses were simultaneously taken on July 6, July 21, August 12. August 30, September 10, September 24, and October 22, 2014. The $\mathrm{CH}_{4}$ and $\mathrm{N}_{2} \mathrm{O}$ fluxes were determined by the static chamber-GC method as shown in our previous studies (Zou et al., 2005; Liu et al., 2012), and the methods for gas flux measurements physicochemical properties and microbial genes abundance analyses were similar to those described in windrow composting experiment.

The three statistics $R^{2}$ (coefficient of determination), RMSE (root mean square error), and MEF (modeling efficiency) were used for model evaluation (Table 3). All statistical analyses were performed using JMP software version 9.0.2 for Windows (SAS Inst., Cary, NC, USA, 2010).

\section{RESULTS}

There was a trade-off between $\mathrm{CH}_{4}$ and $\mathrm{N}_{2} \mathrm{O}$ fluxes during manure windrow composting (Figure 1). Substantial $\mathrm{CH}_{4}$ emissions occurred primarily during thermophilic Phase I. During Phase I, $\mathrm{CH}_{4}$ fluxes ascended rapidly until the peak fluxes were attained approximately 4 days after the onset of composting. Thereafter, $\mathrm{CH}_{4}$ emission was dramatically decreased by pile turning and then remained lower release rate, which was closely associated with decreases in pile temperature (Table 2). In contrast, $\mathrm{N}_{2} \mathrm{O}$ fluxes stayed relatively lower during Phase I, and they gradually increased during phase II. Eventually, $\mathrm{N}_{2} \mathrm{O}$ fluxes were highest by the end of manure compositing (Figure 1).

Over the 65-day period of manure composting, $\mathrm{CH}_{4}$-C fluxes varied from 0.4 to $134.5 \mathrm{~g} \mathrm{~m}^{-2} \mathrm{~d}^{-1}$, with an average flux of $17.1 \mathrm{~g} \mathrm{~m}^{-2} \mathrm{~d}^{-1}$ (Figure 1). Cumulative $\mathrm{CH}_{4}$ emissions in terms 


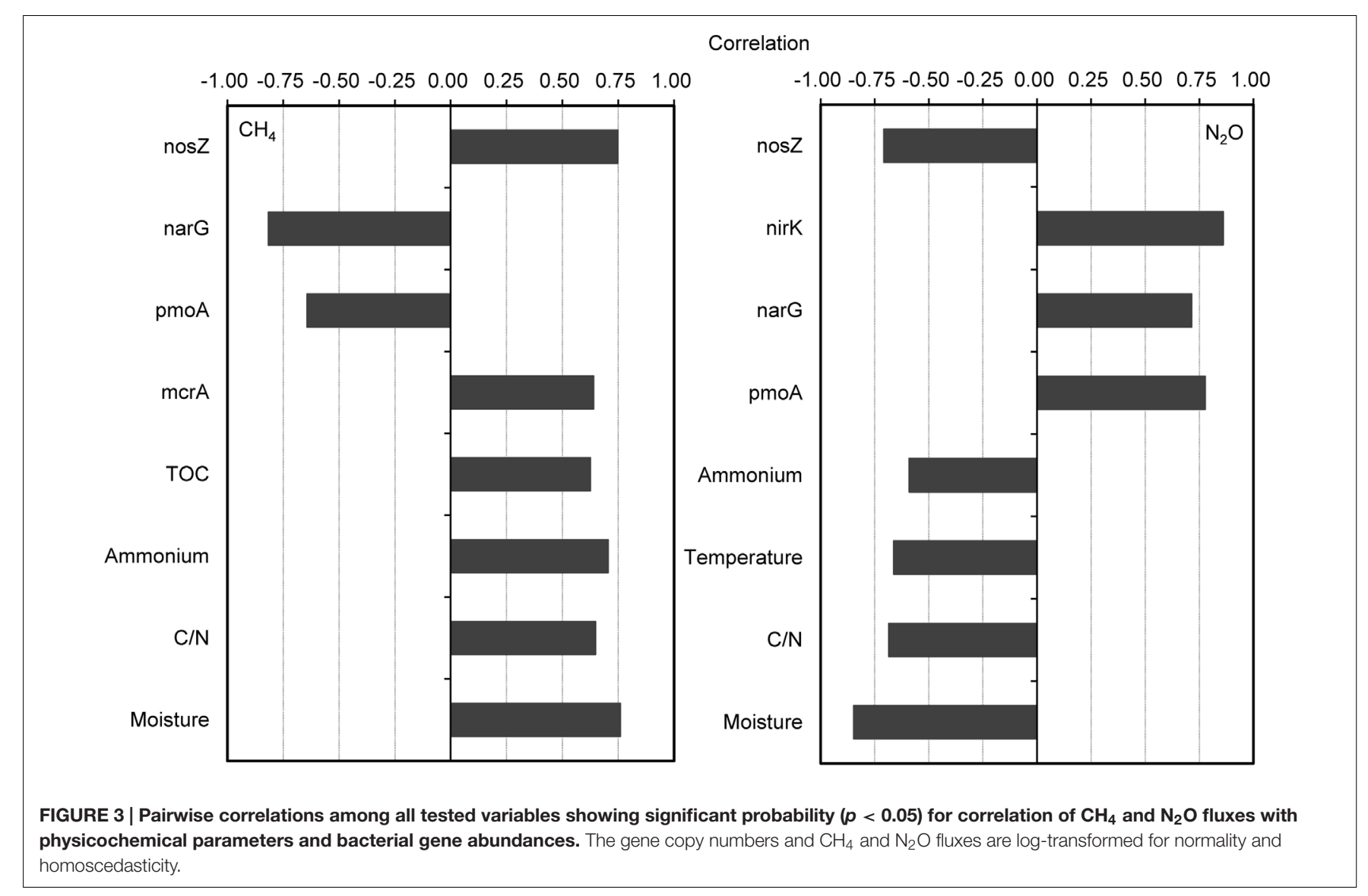

of initial windrow surface area were $1.1 \mathrm{~kg} \mathrm{~m}^{-2}$, being equivalent to $0.8 \%$ of total $\mathrm{C}$ in initial manure dry weight (MCF). The fluxes of $\mathrm{N}_{2} \mathrm{O}-\mathrm{N}$ varied within the range of $15.0-95.0 \mathrm{mg} \mathrm{m}^{-2} \mathrm{~d}^{-1}$ during Phase I, and rapidly increased from 114.2 to $1621.1 \mathrm{mg}$ $\mathrm{m}^{-2} \mathrm{~d}^{-1}$ during Phase II, dedicating to an average of $383.3 \mathrm{mg}$ $\mathrm{m}^{-2} \mathrm{~d}^{-1}$ over the whole composting process. Cumulative $\mathrm{N}_{2} \mathrm{O}$ emissions in terms of initial windrow surface area were $25.1 \mathrm{~g}$ $\mathrm{m}^{-2}$, representing $0.18 \mathrm{~kg}$ per ton of MDW. The emission factor of $\mathrm{N}_{2} \mathrm{O}$ (EF, percentage of initial $\mathrm{N}$ in manure compost pile emitted as $\mathrm{N}_{2} \mathrm{O}-\mathrm{N}$ ) was estimated to be $1.2 \%$ for composting windrow.

A contrasting time course pattern of $m c r A$ and $p m o A$ genes abundance was detected during windrow composting. The measured abundances of $m c r A$ were the highest at the onset of composting, being average $6.26 \log$ copy numbers. $\mathrm{g}^{-1}$ (Figure 2). Thereafter, the $m c r A$ gene abundance gradually decreased until it remained stable around $\sim 5.0 \log$ copy numbers. $\mathrm{g}^{-1}$. Relative to a smaller variation of $m c r A$ gene abundance, $p m o A$ gene abundance showed larger variation (variation range: 5.11-8.05 $\log$ copy numbers. $\mathrm{g}^{-1}$ ) over the composting process. The measured abundance of $p m o A$ decreased in the first week and then kept an ascending trend over the composting process, reaching the greatest abundance by the end of windrow composting (Figure 2).

For the functional genes involved in $\mathrm{N}_{2} \mathrm{O}$ emissions, the abundance of amoA, narG, nirK, and nirS genes shared a rising pattern over the composting process, in contrast to a declining trend for norB and nos $Z$ genes abundance (Figure 2). Over the composting process, predominant genes in bacterial community shifted from norB and nos $Z$ genes (6.76-6.91 log copy numbers. $\mathrm{g}^{-1}$ ) during Phase I to nirK gene (6.78 log copy numbers. $\mathrm{g}^{-1}$ ) during Phase II (Figure 2). The amoA gene abundance stayed the lowest $\left(\sim 3.10 \mathrm{log}\right.$ copy numbers. $\left.\mathrm{g}^{-1}\right)$ over the whole windrow composting.

The $\mathrm{CH}_{4}$ fluxes showed strong positive correlations with compost material parameters including moisture, $\mathrm{C} / \mathrm{N}$ ratio, $\mathrm{NH}_{4}{ }^{+}-\mathrm{N}$, and TOC during the composting process (Figure 3). The $\mathrm{CH}_{4}$ fluxes were also positively correlated with $\mathrm{mcrA}$ and $n o s Z$ gene numbers, but negatively correlated with $p m o A$ and narG gene numbers. For the relative abundance of functional genes group, $\mathrm{CH}_{4}$ fluxes were positively correlated with $m c r A / p m o A(r=0.78, p=0.01)$. Besides strong negative correlations between $\mathrm{N}_{2} \mathrm{O}$ fluxes and pile moisture, temperature and $\mathrm{C} / \mathrm{N}$ ratio, $\mathrm{N}_{2} \mathrm{O}$ fluxes showed significant positive correlations with $p m o A$, narG, and nirK genes abundance, but negatively correlated with nos $Z$ gene abundance (Figure 3). The $\mathrm{N}_{2} \mathrm{O}$ fluxes were positively correlated with relative abundances of functional gene group (nirK + nirS)/nos $Z$ $(r=0.90, p=0.001)$.

During the composting process, TOC, TN, moisture and $\mathrm{C} / \mathrm{N}$ ratio were significantly correlated with each other, acting as a group to correlate with $p m o A$, narG, nirK, and nirS genes 


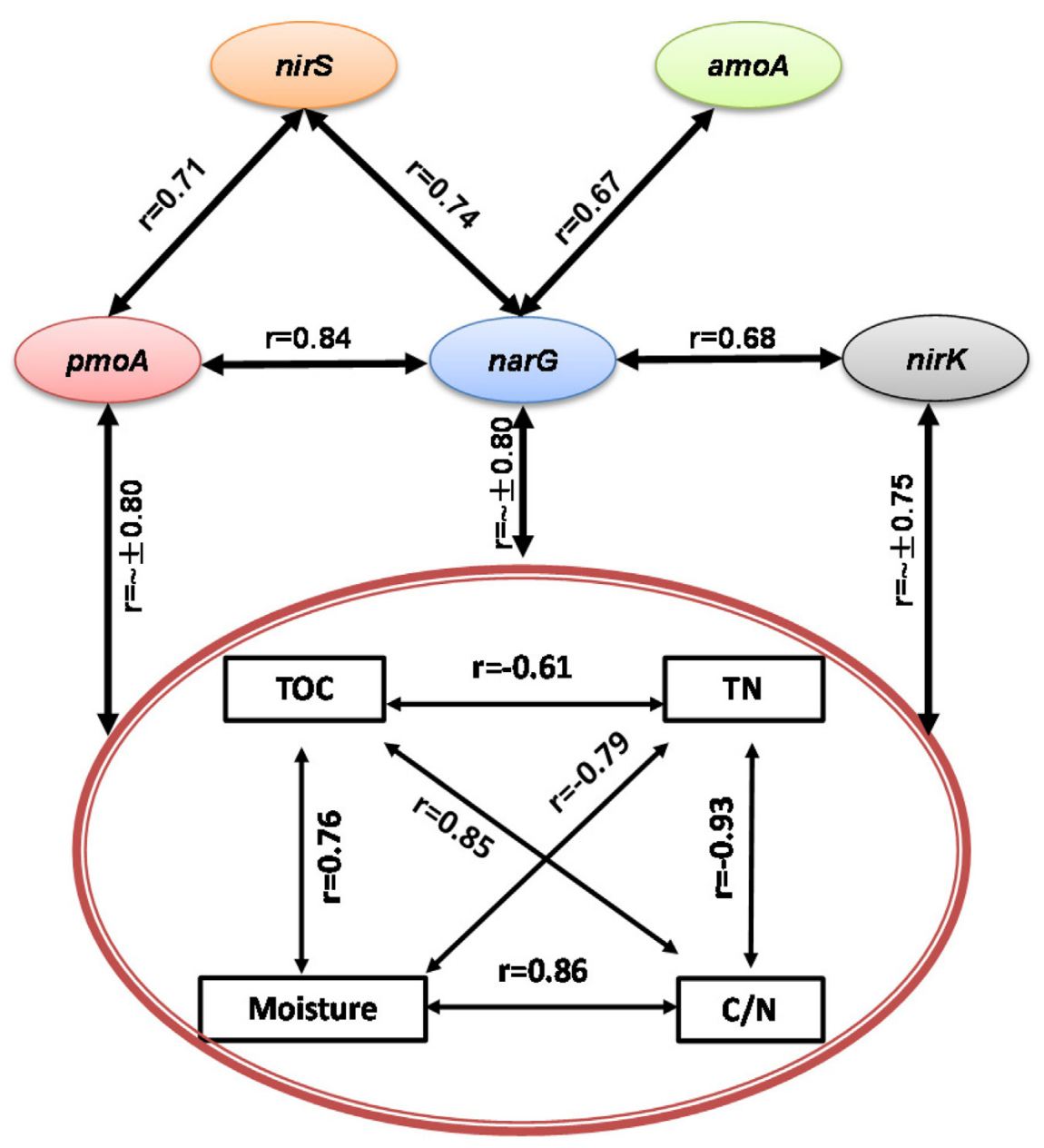

FIGURE 4 | Pairwise correlations among all tested variables showing some interacting physicochemical parameters significantly correlated with bacterial gene abundances $(p<0.05)$.

abundance and $\mathrm{CH}_{4}$ and $\mathrm{N}_{2} \mathrm{O}$ fluxes (Figures 3, 4). Among functional genes, the abundance of $\operatorname{pmoA}$, narG, and nirS genes were correlated with each other. Besides, the narG gene abundance was correlated with $a m o A$ and nirK genes, but amoA gene abundance was not significantly correlated with nirK gene (Figure 4).

A stepwise regression analysis was conducted for modeling $\mathrm{CH}_{4}$ and $\mathrm{N}_{2} \mathrm{O}$ fluxes with bacterial functional gene abundances and physicochemical parameters (Table 3). The model based on bacterial functional genes $m c r A / p m o A$ alone can explain $55 \%$ of the variance in $\mathrm{CH}_{4}$ fluxes over the composting process $\left(\mathrm{Y}_{\mathrm{Cl}}\right.$, Table 3). While integrating morA gene abundance together with pile temperature $(\mathrm{T})$, however, the simulated regression model explained as high as $94 \%$ of the variance in $\mathrm{CH}_{4}$ fluxes $\left(\mathrm{Y}_{\mathrm{C} 2}\right.$, Table 3). Furthermore, the regression model including $\mathrm{mcr} A$ gene, $\mathrm{T}$ and $\mathrm{NH}_{4}{ }^{+}-\mathrm{N}$ significantly lowered the model error and increased model efficiency, which can almost fully project the time course of $\mathrm{CH}_{4}$ fluxes $\left(\mathrm{Y}_{\mathrm{C} 3}\right.$, Table 3 and Figure 5). Among the regression models, the model based on pile temperature (T), mcrA and $\mathrm{NH}_{4}{ }^{+}-\mathrm{N}$ appeared to be the best fit for $\mathrm{CH}_{4}$ flux variance when the statistics $R^{2}, P, R M S E$, and $M E F$ were comprehensively evaluated (Table 3 ).

As shown in the stepwise regression model, a functional genes group, (nirK+nirS)/nos $Z$ acted as a good proxy for predicting dynamics of $\mathrm{N}_{2} \mathrm{O}$ fluxes $\left(\mathrm{Y}_{\mathrm{N} 1}\right.$, Table 1). While taking nirK minus nos $Z$ genes into account but excluding nirS genes, the performance of simulated model was significantly improved, explaining as high as $92 \%$ of the variance in $\mathrm{N}_{2} \mathrm{O}$ fluxes during windrow composting $\left(\mathrm{Y}_{\mathrm{N} 2}\right.$, Table 1). Besides nirK and nos $Z$ genes, $p m o A$ gene was also responsible for the variance in $\mathrm{N}_{2} \mathrm{O}$ fluxes as shown in pairwise correlation (Figure 3). Indeed, about $95 \%$ of the variance in $\mathrm{N}_{2} \mathrm{O}$ fluxes can be explained by the model based on linear regression of nirK, nos $Z$, and $p m o A$ genes abundance $\left(\mathrm{Y}_{\mathrm{N} 3}\right.$, Table 1). Compared to the $\mathrm{Y}_{\mathrm{N} 1}$ and $\mathrm{Y}_{\mathrm{N} 2}$ models, the $\mathrm{Y}_{\mathrm{N} 3}$ model including $p m o A$ gene abundance as an additional predictor was able to minimize the uncertainty in $\mathrm{N}_{2} \mathrm{O}$ flux estimates (Table 1 and Figure 5).

The simulated OLS models were also applicable to paddy rice cropping systems (Table 3 and Figures 6, 7). In rice paddies, about $75 \%$ of the seasonal variance in $\mathrm{CH}_{4}$ fluxes as a response to 

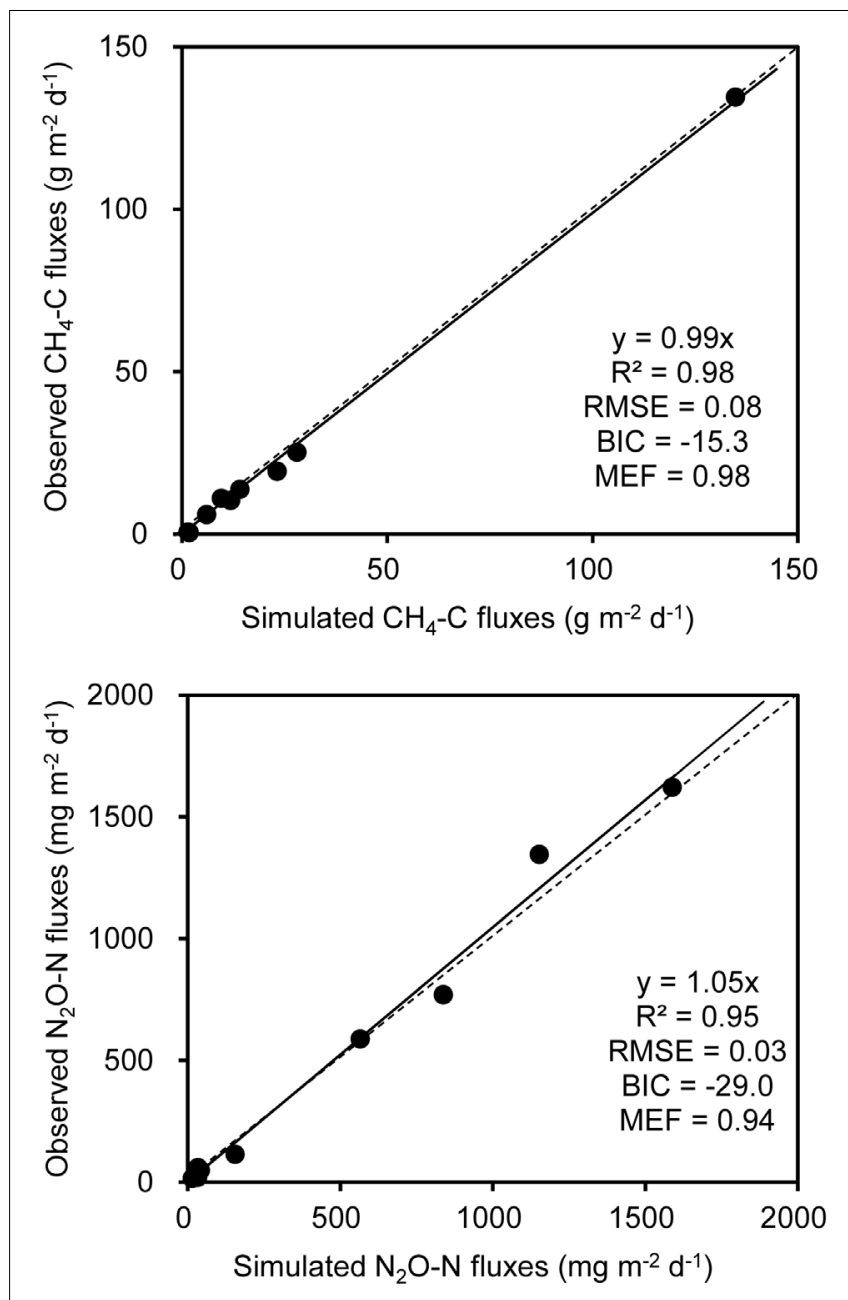

FIGURE 5 | Comparison of observed and modeled $\mathrm{CH}_{4}$ and $\mathrm{N}_{2} \mathrm{O}$ fluxes during dairy manure windrow composting. Estimation of parameters in models for $\mathrm{CH}_{4}\left(\mathrm{Y}_{\mathrm{C} 3}\right)$ and $\mathrm{N}_{2} \mathrm{O}\left(\mathrm{Y}_{\mathrm{N} 3}\right)$ are shown in Table 1. The slope, $R^{2}$, $\mathrm{BIC}$, the root mean square error (RMSE), and model efficiency (MEF) are indicated at the bottom right of each panel.

elevated atmospheric $\mathrm{CO}_{2}$ concentration and rising temperature can be explained by re-parameterized $\mathrm{Y}_{\mathrm{C} 3}$ model based on linear combination of soil temperature, $m c r A$ and $\mathrm{NH}_{4}{ }^{+}-\mathrm{N}$ (Figure 7). Similarly, the re-parameterized nirK, nos $Z$, and pmoA genes abundance in $\mathrm{Y}_{\mathrm{N} 3}$ model can largely reflect seasonal $\mathrm{CH}_{4}$ fluxes response to elevated atmospheric $\mathrm{CO}_{2}$ concentration and rising temperature in paddy rice cropping systems (Figure 7).

\section{DISCUSSION}

Manure composting has been recognized as an important source of $\mathrm{CH}_{4}$ and $\mathrm{N}_{2} \mathrm{O}$ to atmosphere [Intergovernmental Panel on Climate Change (IPCC), 2006; Chadwick et al., 2011; Hou et al., 2015; Owen and Silver, 2015; Pardo et al., 2015]. The IPCC guidelines introduce the terms of MCF (methane conversion factor) and $\mathrm{EF}$ (emission factor of $\mathrm{N}$ for $\mathrm{N}_{2} \mathrm{O}$ ) for accounting
$\mathrm{CH}_{4}$ and $\mathrm{N}_{2} \mathrm{O}$ emissions from manure composting, respectively [Intergovernmental Panel on Climate Change (IPCC), 2006]. In the present study, total $\mathrm{CH}_{4}$ and $\mathrm{N}_{2} \mathrm{O}$ emissions were estimated to be $1.1 \mathrm{~kg} \mathrm{~m}^{-2}$ and $25.1 \mathrm{~g} \mathrm{~m}^{-2}$, being equivalent to a MCF of $0.8 \%$ and an EF of $1.2 \%$ for composting windrow, respectively. The value of MCF in this study falls well within the IPCC default value range of $0.5-1.5 \%$ in composting windrows [Intergovernmental Panel on Climate Change (IPCC), 2006]. The estimated $\mathrm{EF}(1.2 \%)$ in this study is slightly greater than the IPCC default EF of 1.0\% [Intergovernmental Panel on Climate Change (IPCC), 2006], but highly close to the recent estimates (mean of EF: $1.2 \%$ ) based on a summary of available data on composting windrow by Pardo et al. (2015).

Measurements of GHG fluxes showed a trade-off between $\mathrm{CH}_{4}$ and $\mathrm{N}_{2} \mathrm{O}$ fluxes, as previously found in rice paddy soils and windrow compost (Cai et al., 1997; Hou et al., 2001; Zou et al., 2005; Ahn et al., 2011; Shen et al., 2011). Consistent with previous studies (Hou et al., 2001; Sánchez-Monedero et al., 2010; Sharma et al., 2011; Chen et al., 2014), substantial $\mathrm{CH}_{4}$ emissions occurred mainly in the early stage of manure composting process. In contrast, remarkable $\mathrm{N}_{2} \mathrm{O}$ emissions were triggered around the middle stage of the composting when pile temperature started to decline and oxygen availability was limited (Fukumoto et al., 2003; Xu et al., 2007; Ahn et al., 2011; Tsutsui et al., 2013; Wang et al., 2013). In addition, norB and nos $Z$ genes were relatively predominant during the early stage of composting (Figure 2), suggesting that much $\mathrm{N}_{2} \mathrm{O}$ was further transformed into $\mathrm{N}_{2}$ as the final product in denitrification.

Consistent with the first hypothesis prediction, changes in physicochemical parameters shaped different time course patterns of $\mathrm{CH}_{4}$ - and $\mathrm{N}_{2} \mathrm{O}$-related functional genes (Gödde and Conrad, 1999; Holtan-hartwig et al., 2002; Kandeler et al., 2006; Zhou et al., 2011; Zhang et al., 2015). Correlation analyses showed that the abundance of pmoA, narG, nirK, and nirS genes shared negative correlations with pile temperature $(r=\sim-0.70, p<0.05)$, moisture, TOC, and $\mathrm{C} / \mathrm{N}$ ratio, and positive correlations with TN (Figure 4), suggesting that changes in interacting physicochemical parameters in the pile shaped the dynamic pattern of the pmoA, narG, nirK, and nirS genes (Figure 4), in line with the results obtained by Hallin et al. (2009) showing that nitrate reducers and denitrifiers were closely related to soil $\mathrm{TOC}, \mathrm{TN}$, and $\mathrm{C} / \mathrm{N}$ ratio in a 50-year-old fertilization experiment. Similar relationships between methanotrophs abundances and abiotic parameters were found in landfill cover soils (Kumaresan et al., 2009; Lin et al., 2009). Some studies also reported the relationships between denitrifiers and physicochemical parameters, such as correlations of nirK and nirS genes abundance with pile temperature (Zhang et al., 2015), and correlations of narG, nirK and nos $Z$ genes abundance with soil TOC (Kandeler et al., 2006; Zhou et al., 2011).

Significant correlations of $n o s \mathrm{Z}$ gene abundance with $\mathrm{NH}_{4}{ }^{+}$ and $\mathrm{NO}_{2}{ }^{-}$suggested that nos $\mathrm{Z}$ gene abundance dynamics was mainly associated with substrate availabilities. The mcrA and amoA genes abundance did not show significant correlations with any of physicochemical parameters, and amoA gene abundance was, on average, much lower than nitrate reducers and denitrifiers 


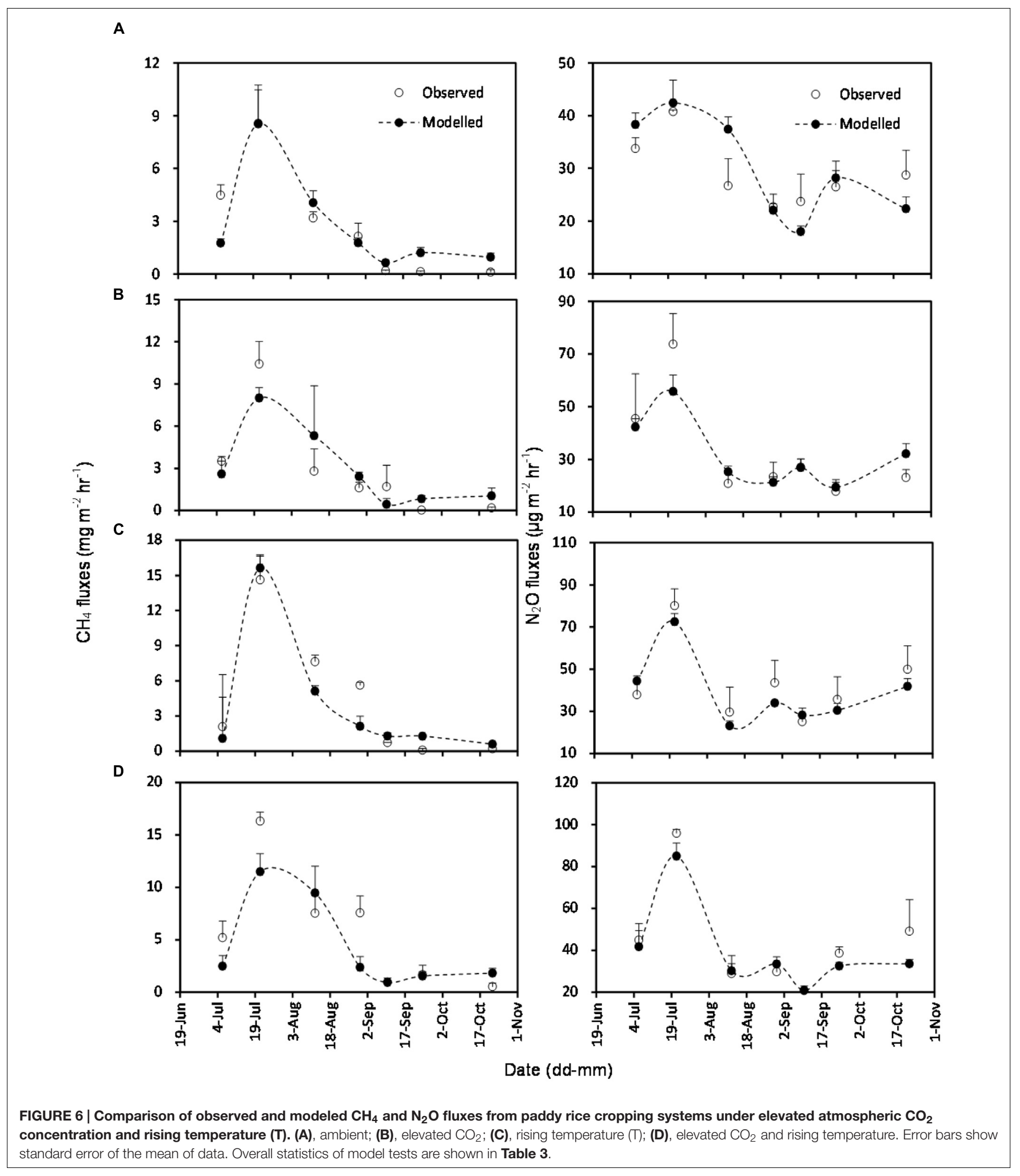

(narG, nirK nirS, norB, and nosZ) abundance, suggesting that denitrification was much stronger than nitrification during windrow composting (Hao et al., 2001). Partially due to $\mathrm{pH}$ remaining stable around 8.0 during windrow composting, pile
$\mathrm{pH}$ did not show significant correlations with any of bacterial functional genes in this study, consistent with Kandeler et al. (2006) but contrary to other previous studies (Deiglmayr et al., 2004; Bárta et al., 2010; Zhang et al., 2015). In addition, 

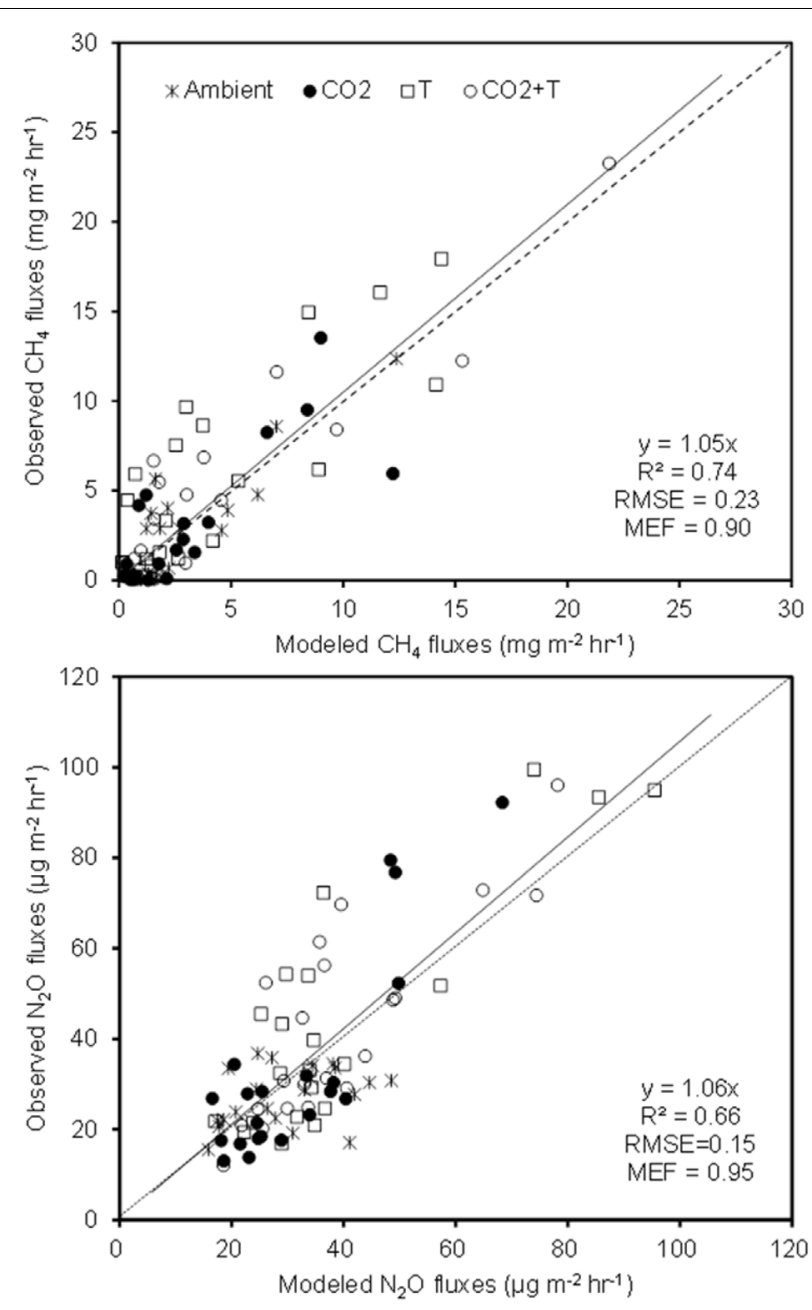

FIGURE 7 | The $\mathrm{Y}_{\mathrm{C} 3}$ and $\mathrm{Y}_{\mathrm{N} 3}$ models tested against field measurements in paddy rice cropping systems under elevated atmospheric $\mathrm{CO}_{2}$ and rising temperature (T).

$\mathrm{NH}_{4}{ }^{+}$was slightly correlated with narG, nirK, and nirS genes abundance $(p=\sim 0.07)$, while $\mathrm{NO}_{3}{ }^{-}$did not show significant correlations with nitrate reducer and denitrifier abundances, which might suggest that nitrate in pile manure is not important for denitrifiers (Tiedje, 1988; Mergel et al., 2001; Avrahami et al., 2002; Liu et al., 2003; Kandeler et al., 2006; Zhang et al., 2015).

The $\mathrm{NH}_{4}{ }^{+}$and pmoA gene were involved in $\mathrm{CH}_{4}$ and $\mathrm{N}_{2} \mathrm{O}$ emissions, respectively, which partially supported the second hypothesis that some specific physicochemical parameters and compositional bacterial enzymes encoded by relevant genes would be multifunctional as involved both in $\mathrm{CH}_{4}$ and $\mathrm{N}_{2} \mathrm{O}$. The $\mathrm{CH}_{4}$ fluxes showed a positive correlation with $\mathrm{NH}_{4}{ }^{+}$, and $\mathrm{NH}_{4}{ }^{+}$was selected as an indicator in the stepwise regression model (Table 3 and Figure 3). A great many studies have revealed that $\mathrm{NH}_{4}{ }^{+}$has an inhibitory effect on $\mathrm{CH}_{4}$ oxidization through either competition for methane monooxygenase or generation of toxic hydroxylamine and nitrite from ammonium oxidation
(Steudler et al., 1989; Bosse et al., 1993; Dunfield and Knowles, 1995; Hanson and Hanson, 1996; Duan et al., 2013; Dam et al., 2014; Karbin et al., 2015), although stimulation effects or no effects of $\mathrm{NH}_{4}{ }^{+}$on methanotrophs were reported in some other studies (Dunfield et al., 1995; Delgado and Mosier, 1996; Dan et al., 2001; Krüger and Frenzel, 2003; Shrestha et al., 2010; $\mathrm{Hu}$ and $\mathrm{Lu}, 2015)$. The $\mathrm{CH}_{4}$ fluxes were negatively related with narG but positively related with nos $Z$ genes abundances, which might be due to the significant correlations of narG with $p m o A$ genes $(r=0.84, p=0.005)$ and of nos $Z$ genes with $\mathrm{NH}_{4}{ }^{+}(r=0.76, p=0.02)$. In addition, $\mathrm{N}_{2} \mathrm{O}$ fluxes were correlated with $p m o A$ gene abundances, and $p m o A$ gene abundances were included in the regression model (Table 3 and Figure 3), which might suggest denitrification with methane as external carbon source. Some studies reported that aerobic methane-oxidation coupled to denitrification is accomplished by aerobic methanotrophs oxidizing methane and releasing soluble organics that are used by coexisting denitrifiers as electron donors for denitrification (Modin et al., 2007). Indeed, the pmoA, narG, and nirS gene abundances were correlated in this study (Figure 4).

Both $m c r A$ and $p m o A$ genes abundances were correlated with $\mathrm{CH}_{4}$ fluxes, and the balance of $m c r A / p m o A$ genes abundance was selected as a good indicator in the regression model (Table 3 and Figure 3), indicating that both methanogens and methanotrophs played important roles in $\mathrm{CH}_{4}$ fluxes from composting windrow. The $\mathrm{N}_{2} \mathrm{O}$ fluxes were positively correlated with narG and nirK genes abundance, but negatively correlated with nos $Z$ gene abundance. However, $\mathrm{N}_{2} \mathrm{O}$ fluxes were not correlated with nirS gene abundances in this study. The nitrite reducers with $\mathrm{Cu}$ containing enzyme encoded by nirK gene are generally believed to be more important than those with cytochrome cdl nitrite reductase encoded by nirS gene in the nitrite reduction step during manure composting (Yoshida et al., 2009; Bárta et al., 2010; Chen et al., 2010; Zhou et al., 2011; Zhang et al., 2015).

Based on physicochemical and biological variables measurements during the composting and their correlation and regression analyses, we developed a schematic model that explains the dynamics of $\mathrm{CH}_{4}$ and $\mathrm{N}_{2} \mathrm{O}$ fluxes associated with bacterial functional genes and physicochemical parameters during manure composting (Figure 8). The schematic model shows how the prevalence of bacteria is involved in key steps in the process of $\mathrm{CH}_{4}$ and $\mathrm{N}_{2} \mathrm{O}$ emissions, and the $\mathrm{CH}_{4}$ and $\mathrm{N}_{2} \mathrm{O}$ fluxes during windrow composting are controlled by the interplay of enzyme encoding bacterial functional genes (Figure 8). In the schematic model, some physicochemical parameters are correlated with each other and interacting to shape the dynamics of bacterial functional gene abundance. Besides bacterial functional genes are directly involved in $\mathrm{CH}_{4}$ or $\mathrm{N}_{2} \mathrm{O}$ emissions, $\mathrm{CH}_{4}$ oxidization and denitrification processes interact together, where $\mathrm{NH}_{4}{ }^{+}$has inhibitory effects on $\mathrm{CH}_{4}$ oxidization and pmoA gene abundance can facilitate denitrification with methane as external carbon source (Figure 8). Some studies stated that the aerobic methanotrophic bacteria are particularly useful for discovering and analyzing diverse mechanisms for nitrification and denitrification processes (Stein and Klotz, 2011; Zhou et al., 2014). By testing against samples in paddy rice cropping systems 


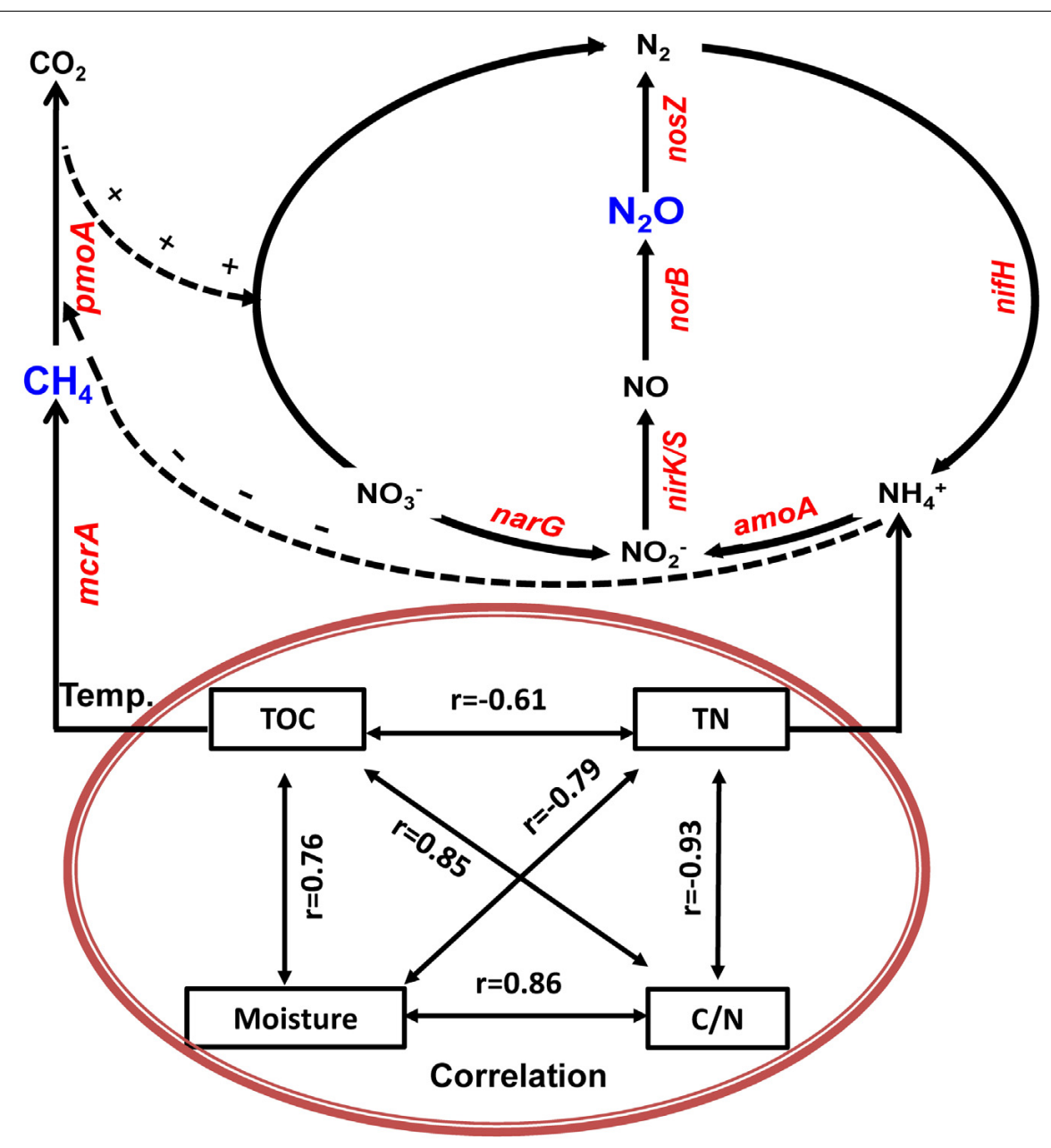

FIGURE 8 | Generalized schematic model showing predicted $\mathrm{CH}_{4}$ and $\mathrm{N}_{2} \mathrm{O}$ fluxes as a function of bacterial functional genes and physicochemical parameters during manure composting. Physicochemical parameters of compost manure material including total organic carbon (TOC), total nitrogen (TN), moisture and carbon/nitrogen ratio $(\mathrm{C} / \mathrm{N})$ are correlated with each other, and interacting to shape the dynamics of bacterial functional gene abundance. Solid lines indicate direct connections. Dashed lines refer to indirect connections where ammonium has inhibitory effects on $\mathrm{CH}_{4}$ oxidization, while $\mathrm{CH}_{4}$ oxidization facilitates denitrification with methane as external carbon source.

(Table 3 and Figures 6, 7), the simulated models can also be applicable to predicting seasonal dynamics of $\mathrm{CH}_{4}$ and $\mathrm{N}_{2} \mathrm{O}$ fluxes as responses to elevated atmospheric $\mathrm{CO}_{2}$ and rising temperature.

Bacterial genes key functional to $\mathrm{CH}_{4}$ and $\mathrm{N}_{2} \mathrm{O}$ fluxes identified in this study may be used as strategies for mitigating GHGs. For example, biochar application can significantly reduce both $\mathrm{CH}_{4}$ and $\mathrm{N}_{2} \mathrm{O}$ emissions by depressing nirK and morA while stimulating nos $Z$ and $p m o A$ genes abundances during manure composting (Sonoki et al., 2013; Wang et al., 2013). We noted that limitations on the use of qPCR for investigation of targeted genes also exist as results of PCR-bias, disturbance by DNA from dead cell, detecting only DNA copy numbers but not RNA transcriptional activity, lacking information regarding detailed community structures of specific microorganisms. The cDNA-based technologies and high throughout strategies, such as reverse transcription quantitative PCR, Illumina sequencing, and Gene Chip, will be very useful for a deeper understanding the characteristics of the functional genes and specific microbial groups, as well as their relationships with GHG emissions.

\section{CONCLUSION}

We presented the quantitative study illustrating interactions between different bacterial activities and their role in controlling $\mathrm{CH}_{4}$ and $\mathrm{N}_{2} \mathrm{O}$ fluxes as a response to changes in physicochemical parameters during windrow composting. This study also presented the quantitative assessment of $\mathrm{CH}_{4}$ and $\mathrm{N}_{2} \mathrm{O}$ fluxes based on multiple microbial gene abundances at the functional levels in composting windrow. Additional studies in this area are highly needed to extend such capabilities and allow us to quantitatively address microbial contributions to GHG fluxes from soils and manure management systems. This is particularly important, as it is widely believed that microorganisms play important roles in global carbon and 
nitrogen biogeochemical cycles, yet they are generally not included in current biogeochemical models for carbon and nitrogen cycles.

\section{AUTHOR CONTRIBUTIONS}

SqL and JZ conceived this study. SqL has the main responsibility for microbial sampling and microbial analyses for this study. SwL and QS provided valuable input for the design and data analyses of this study. LS, XG, and YJ performed qPCR analyses and gas sampling. SwL, SqL, and JZ performed the statistical analyses and wrote the paper. All authors edited and approved the final manuscript.

\section{REFERENCES}

Ahn, H. K., Mulbry, W., White, J. W., and Kondrad, S. L. (2011). Pile mixing increases greenhouse gas emissions during composting of dairy manure. Bioresour. Technol. 102, 2904-2909. doi: 10.1016/j.biortech.2010. 10.142

Angnes, G., Nicoloso, R. S., da Silva, M. L., de Oliveira, P. A., Higarashi, M. M., Mezzari, M. P., et al. (2013). Correlating denitrifying catabolic genes with $\mathrm{N}_{2} \mathrm{O}$ and $\mathrm{N}_{2}$ emissions from swine slurry composting. Bioresour. Technol. 140, 368-375. doi: 10.1016/j.biortech.2013.04.112

Avrahami, S., Conrad, R., and Braker, G. (2002). Effect of soil ammonium concentration on $\mathrm{N}_{2} \mathrm{O}$ release and on the community structure of ammonia oxidizers and denitrifiers. Appl. Environ. Microbiol. 68, 5685-5692. doi: 10.1128/AEM.68.11.5685-5692.2002

Bárta, J., Applová, M., Vaněk, D., Krištůfková, M., and Šantrůčková, H. (2010). Effect of avalilabe $\mathrm{P}$ and phenolics on mineral $\mathrm{N}$ release in acidified spruce forest: connection with lignin-degrading enzymes and bacteria and fungal. Biogeochemistry 97, 71-87. doi: 10.1007/s10533-009-9363-3

Bosse, U., Frenzel, P., and Conrad, R. (1993). Inhibition of methane oxidation by ammonium in the surface-layer of a littoral sediment. FEMS Microbiol. Ecol. 13, 123-134. doi: 10.1111/j.1574-6941.1993.tb00058.x

Braker, G., Fesefeldt, A., and Witzel, K. P. (1998). Development of PCR primer systems for amplification of nitrite reductase genes (nirK and nirS) to detect denitrifying bacteria in environmental samples. Appl. Environ. Microbiol. 64, 3769-3775.

Braker, G., and Tiedje, J. M. (2003). Nitric oxide reductase (norB) genes from pure cultures and environmental samples. Appl. Environ. Microbiol. 69, 3476-3483. doi: 10.1128/AEM.69.6.3476-3483.2003

Cai, C., Yin, X., He, S., Jiang, W., Si, C., Struik, P. C., et al. (2015). Responses of wheat and rice to factorial combinations of ambient and elevated $\mathrm{CO}_{2}$ and temperature in FACE experiments. Glob. Change Biol. 22, 856-874. doi: $10.1111 /$ gcb.13065

Cai, Z., Xing, G., Yan, X., Xu, H., Tsuruta, H., Yagi, K., et al. (1997). Methane and nitrous oxide emissions from rice paddy fields as affected by nitrogen fertilisers and water management. Plant Soil 196, 7-14. doi: 10.1023/A:1004263405020

Castaldi, P., Garau, G., and Melis, P. (2008). Maturity assessment of compost from municipal solid waste through the study of enzyme activities and water-soluble fractions. Waste Manage. 28, 534-540. doi: 10.1016/j.wasman.2007.02.002

Chadwick, D., Sommer, S., Thorman, R., Fangueiro, D., Cardenas, L., Amon, B., et al. (2011). Manure management: implications for greenhouse gas emissions. Anim. Feed. Sci. Technol. 16, 514-531. doi: 10.1016/j.anifeedsci.2011.04.036

Chen, R., Wang, Y., Wei, S., Wang, W., and Lin, X. (2014). Windrow composting mitigated $\mathrm{CH} 4$ emissions: characterization of methanogenic and methanotrophic communities in manure management. FEMS Microbiol. Ecol. 90, 575-586. doi: 10.1111/1574-6941.12417

Chen, Z., Luo, X., Hu, R., Wu, M., Wu, J., and Wei, W. (2010). Impact of long-term fertilization on the composition of denitrifier communities based on nitrite reductase analyses in a paddy soil. Microb. Ecol. 60, 850-861. doi: 10.1007/ s00248-010-9700-z

\section{FUNDING}

This work was supported by the National Basic Research Program of China (2015CB150502), National Natural Science Foundation of China (NSFC 41225003, 41401321), Fundamental Research Funds for the Central Universities (KYT201404 and KYZ201621, NAU), and Ministry of Education 111 project (B12009) and PADA.

\section{ACKNOWLEDGMENT}

We thank Dr. Evan Siemann at Rice University for the help in language editing of this manuscript.

Chen, Z., Zhang, J., Xiong, Z., Pan, G., and Müller, C. (2016). Enhanced gross nitrogen transformation rates and nitrogen supply in paddy field under elevated atmospheric carbon dioxide and temperature. Soil Biol. Biochem. 94, 80-87. doi: 10.1016/j.soilbio.2015.11.025

Costello, A. M., and Lidstrom, M. E. (1999). Molecular characterization of functional and phylogenetic genes from natural populations of methanotrophs in lake sediments. Appl. Environ. Microbiol. 65, 5066-5074.

Czepiel, P., Douglas, E., Harriss, R., and Crill, P. (1996). Measurements of $\mathrm{N}_{2} \mathrm{O}$ from composted organic wastes. Environ. Sci. Technol. 30, 2519-2525. doi: $10.1021 /$ es950841j

Dam, B., Dam, S., Kim, Y., and Liesack, W. (2014). Ammonium induces differential expression of methane and nitrogen metabolism-related genes in Methylocystis sp. strain SC2. Environ. Microbiol. 16, 3115-3127. doi: 10.1111/1462-2920. 12367

Dan, J. G., Krüger, M., Frenzel, P., and Conrad, R. (2001). Effect of a late season urea fertilization on methane emission from a rice field in Italy. Agric. Ecosyst. Environ. 83, 191-199. doi: 10.1016/S0167-8809(00)00265-6

Deiglmayr, K., Philippot, L., Hartwig, U. A., and Kandeler, E. (2004). Structure and activity of the nitrate-reducing community in the rhizosphere of Lolium perenne and Trifolium repens under long-term elevated atmospheric pCO. FEMS Microbiol. Ecol. 49, 445-454. doi: 10.1016/j.femsec.2004. 04.017

Delgado, J., and Mosier, A. R. (1996). Mitigation alternatives to decrease nitrous oxides emissions and urea-nitrogen loss and their effect on methane flux. J. Environ. Qual. 25, 1105-1111. doi: 10.2134/jeq1996.00472425002500050025x

Duan, Y. F., Elsgaard, L., and Petersen, S. O. (2013). Inhibition of methane oxidation in a slurry surface crust by inorganic nitrogen: an incubation study. J. Environ. Qual. 42, 507-515. doi: 10.2134/jeq2012. 0230

Dunfield, P., and Knowles, R. (1995). Kinetics of inhibition of methane oxidation by nitrate, nitrite and ammonium in a humisol. Appl. Environ. Microbiol. 61, 3129-3135.

Dunfield, P. F., Topp, E., Archambault, C., and Knowles, R. (1995). Effect of nitrogen fertilizers and moisture-content on $\mathrm{CH} 4$ and $\mathrm{N}_{2} \mathrm{O}$ fluxes in a humisolmeasurements in the field and intact soil cores. Biogeochemistry 29, 199-222. doi: 10.1007/BF02186048

Fukumoto, Y., Osada, T., Hanajima, D., and Haga, K. (2003). Patterns and quantities of $\mathrm{NH} 3, \mathrm{~N}_{2} \mathrm{O}$ and $\mathrm{CH} 4$ emissions during swine manure composting without forced aeration-effect of compost pile scale. Bioresour. Technol. 89, 109-114. doi: 10.1016/S0960-8524(03)00060-9

Gödde, M., and Conrad, R. (1999). Immediate and adaptational temperature effects on nitric oxide production and nitrous oxide release from nitrification and denitrification in two soils. Biol. Fertil. Soils 30, 33-40. doi: 10.1007/ s003740050584

Hallin, S., Jones, C. M., Schloter, M., and Phillippot, L. (2009). Relationship between $\mathrm{N}$-cycling communities and ecosystem functioning in a 50-year-old fertilization experiment. ISME J. 3, 597-605. doi: 10.1038/ismej.2008.128

Hanson, R. S., and Hanson, T. E. (1996). Methanotrophic bacteria. Microbiol. Rev. $60,439-471$. 
Hao, X., Chang, C., Larney, F. J., and Travis, G. R. (2001). Greenhouse gas emissions during cattle feedlot manure composting. J. Environ. Qual. 30, 376-386. doi: 10.2134/jeq2001.302376x

Henry, S., Baudoin, E., López-Gutiérrez, J. C., Martin-Laurent, F., Brauman, A., and Philippot, L. (2004). Quantification of denitrifying bacteria in soils by nirK gene targeted real-time PCR. J. Microbiol. Methods 59, 327-335. doi: 10.1016/j. mimet.2004.07.002

Holtan-hartwig, L., Dörsch, P., and Bakken, L. R. (2002). Low tempreture control of soil denitrifying communities: kinetics of $\mathrm{N}_{2} \mathrm{O}$ production and reduction. Soil Biol. Biochem. 34, 1797-1806. doi: 10.1016/S0038-0717(02) 00169-4

Hou, F. S., Milke, M. W., Leung, D. W., and MacPherson, D. J. (2001). Variaions in phytoremediation performance with diesel-contaminated soil. Environ. Technol. 22, 215-222. doi: 10.1080/09593332208618301

Hou, Y., Velthof, G. L., and Oenema, O. (2015). Mitigation of ammonia, nitrous oxide and methane emissions from manure management chains: a meta-analysis and integrated assessment. Glob. Chang. Biol. 21, 1293-1312. doi: $10.1111 /$ gcb. 12767

Hu, A., and Lu, Y. H. (2015). The differential effects of ammonium and nitrate on methanotrophs in rice field soil. Soil Biol. Biochem. 85, 31-38. doi: 10.1016/j. soilbio.2015.02.033

Hu, H. W., Chen, D. L., and He, J. Z. (2015). Microbial regulation of terrestrial nitrous oxide formation: understanding the biological pathways for prediction of emission rates. FEMS Microbiol. Rev. 39, 729-749. doi: 10.1093/femsre/ fuv021

Intergovernmental Panel on Climate Change (IPCC) (2006). IPCC Guidelines for National Greenhouse Gas Inventories. Kanagawa: IPCC/IGES.

Intergovernmental Panel on Climate Change (IPCC) (2013). Climate Change 2013: The Physical Science Basis. Contribution of Working Group I to the Fifth Assessment Report of the Intergovernmental Panel on Climate Change. Cambridge: Cambridge University Press.

Jiang, T., Li, G., Tang, Q., Ma, X., Wang, G., and Schuchardt, F. (2015). Effects of aeration method and aeration rate on greenhouse gas emissions during composting of pig feces in pilot scale. J. Environ. Sci. 31, 124-132. doi: 10.1016/ j.jes.2014.12.005

Kandeler, E., Deiglmayr, K., Tscherko, D., Bru, D., and Philippot, L. (2006). Abundance of narG, nirS, nirK, and nosZ genes of denitrifying bacteria during primary successions of a glacier foreland. Appl. Environ. Microbiol. 72, 5957-5962. doi: 10.1128/AEM.00439-06

Karbin, S., Hagedorn, F., Dawes, M. A., and Niklaus, P. A. (2015). Treeline soil warming does not affect soil methane fluxes and the spatial micro-distribution of methanotrophic bacteria. Soil Biol. Biochem. 86, 164-171. doi: 10.1016/j. soilbio.2015.03.022

Kim, S. Y., Lee, S. H., Freeman, C., Fenner, N., and Kang, H. (2008). Comparative analysis of soil microbial communities and their responses to the short-term drought in bog, fen, and riparian wetlands. Soil Biol. Biochem. 40, 2874-2880. doi: 10.1016/j.soilbio.2008.08.004

Kroon, P. S., Hensen, A., Van den Bulk, W. C. M., Jongejan, P. A. C., and Vermeulen, A. T. (2008). The importance of reducing the systematic error due to non-linearity in $\mathrm{N}_{2} \mathrm{O}$ flux measurements by static chambers. Nutr. Cycl. Agroecosyst. 82, 175-186. doi: 10.1007/s10705-008-9179-x

Krüger, M., and Frenzel, P. (2003). Effects of N-fertilization on CH4 oxidation and production, and consequences for $\mathrm{CH} 4$ emissions from microcosms and rice fields. Glob. Change Biol. 9, 773-784. doi: 10.1046/j.1365-2486.2003.00576.x

Kumaresan, D., Abell, G. C. J., Bodrossy, L., Stralis-Pavese, N., and Murrell, J. C. (2009). Spatial and temporal diversity of methanotrophs in a landfill cover soil are differentially related to soil abiotic factors. Environ. Microbiol. Rep. 5, 398-407. doi: 10.1111/j.1758-2229.2009.00059.x

Larney, F. J., and Hao, X. (2007). A review of composting as a management alternative for beef cattle feedlot manure in southern Alberta. Canada. Bioresour. Technol. 98, 3221-3227. doi: 10.1016/j.biortech.2006.07.005

Lin, B., Monreal, C. M., Tambong, J. T., Miguez, C. B., and Carrasco-Medina, L. (2009). Phylogenetic analysis of methanotrophic communities in cover soils of a landfill in Ontario. Can. J. Microbiol. 55, 1103-1112. doi: 10.1139/w09-069

Liu, S., Qin, Y., Zou, J., and Liu, Q. (2010). Effects of water regime during rice-growing season on annual direct $\mathrm{N}_{2} \mathrm{O}$ emission in a paddy rice-winter wheat roation system in southeast China. Sci. Total Environ. 408, 906-913. doi: 10.1016/j.scitotenv.2009.11.002
Liu, S., Zhang, L., Liu, Q., and Zou, J. (2012). Fe(III) fertilization mitigating net global warming potential and greenhouse gas intensity in paddy rice-wheat roation systems in China. Environ. Pollut. 164, 73-80. doi: 10.1016/j.envpol. 2012.01.029

Liu, X., Tiquia, S. M., Holguin, G., Wu, L., Nold, S. C., Devol, A. H., et al. (2003). Molecular diversity of denitrifying genes in continental margin sediments within the oxygen-deficient zone off the Pacific coast of Mexico. Appl. Environ. Microbiol. 69, 3549-3560. doi: 10.1128/AEM.69.6.3549-3560.2003

Liu, Y., Li, M., Zheng, J., Li, L., Zhang, X., Zheng, J., et al. (2014). Shortterm responses of microbial community and functioning to experimental $\mathrm{CO}_{2}$ enrichment and warming in a Chinese paddy field. Soil Biol. Biochem. 77, 58-68. doi: 10.1016/j.soilbio.2014.06.011

López-Gutiérrez, J. C., Henry, S., Hallet, S., Martin-Laurent, F., Catroux, G., and Philippot, L. (2004). Quantification of a novel group of nitrate-reducing bacteria in the environment by real-time PCR. J. Microbiol. Methods 57, 399-407. doi: 10.1016/j.mimet.2004.02.009

Maeda, K., Hanajima, D., Toyoda, S., Yoshida, N., Morioka, R., and Osada, T. (2011). Microbiology of nitrogen cycle in animal manure compost. Microbiol. Biotechnol. 4, 700-709. doi: 10.1111/j.1751-7915.2010.00236.x

Maeda, K., Morioka, R., Hanajima, D., and Osada, T. (2010a). The impact of using mature compost on nitrous oxide emission and the denitrifier community in the cattle manure composting process. Microb. Ecol. 59, 25-36. doi: 10.1007/ s00248-009-9547-3

Maeda, K., Toyoda, S., Shimojima, R., Osada, T., Hanajima, D., Morioka, R., et al. (2010b). Source of nitrous oxide emissions during the cow manure composting process as revealed by isotopomer analysis of and amoA abundance in Betaproteo bacterial ammonia-oxidizing bacteria. Appl. Environ. Microbiol. 76, 1555-1562. doi: 10.1128/AEM.01394-09

Mergel, A., Schmitz, O., Mallmann, T., and Bothe, H. (2001). Relative abundance of denitrifying and dinitrogen-fixing bacteria in layers of a forest soil. FEMS Microbiol. Ecol. 36, 33-42. doi: 10.1016/S0168-6496(01)00113-1

Modin, O., Fukushi, K., and Yamamoto, K. (2007). Denitrification with methane as external carbon source. Water Res. 41, 2726-2738. doi: 10.1016/j.watres.2007. 02.053

Morales, S. E., Cosart, T., and Holben, W. E. (2010). Bacterial gene abundances as indicators of greenhouse gas emission in soils. ISME J. 4, 799-808. doi: 10.1038 /ismej.2010.8

Mulbry, W., and Ahn, H. (2014). Greenhouse gas emissions during composting of dairy manure: influnce of the timing of pile mixing on total emissions. Biosyst. Eng. 126, 117-122. doi: 10.1016/j.biosystemseng.2014.08.003

Naylor, R., Steinfeld, H., Falcon, W., Galloway, J., Smil, V., Bradford, E., et al. (2005). Agriculture. Losing the links between livestock and land. Science 310, 1621-1622. doi: 10.1126/science. 1117856

Oenema, O., and Tamminga, S. (2005). Nitrogen in global animal production and management options for improving nitrogen use efficiency. Sci. China C Life Sci. $48,871-887$.

Owen, J. J., and Silver, W. L. (2015). Greenhouse gas emissions from dairy manure management: a review of field-based studies. Glob. Change Biol. 21, 550-565. doi: $10.1111 /$ gcb. 12687

Pardo, G., Moral, R., Aguilera, E., and del Prado, A. (2015). Gaseous emissions from management of solid waste: a systematic review. Glob. Change Biol. 21, 1313-1327. doi: 10.1111/gcb.12806

Pereyra, L. P., Hiibel, S. R., Prieto Riquelme, M. V., Reardon, K. F., and Pruden, A. (2010). Detection and quantification of functional genes of cellulose-degrading, fermentative, and sulfate-reducing bacteria and methanogenic archaea. Appl. Environ. Microbiol. 76, 2192-2202. doi: 10.1128/AEM.01285-09

Regan, K., Kammann, C., Hartung, K., Lenhart, K., Müller, C., Philippot, L., et al. (2011). Can differences in microbial abundances help explain enhanced $\mathrm{N}_{2} \mathrm{O}$ emissions in a permanent grassland under elevated atmospheric $\mathrm{CO}_{2}$. Glob. Change Biol. 17, 3176-3186. doi: 10.1111/j.1365-2486.2011.02470.x

Rotthauwe, J. H., Witzel, K. P., and Liesack, W. (1997). The ammonia monooxygenase structural gene amoA as a functional marker: molecular fine-scale analysis of natural ammonia-oxidizing populations. Appl. Environ. Microbiol. 63, 4704-4712.

Sánchez-Monedero, M. A., Serramiá, N., Civantos, C. G., FernándezHernández, A., and Roig, A. (2010). Greenhouse gas emissions during composting of two-phase olive mill wastes with different agroindustrial by-products. Chemosphere 81, 18-25. doi: 10.1016/j.chemosphere.2010.07.022 
Scala, D. J., and Kerkhof, L. J. (1998). Nitrous oxide reductase (nosZ) gene-specific PCR primers for detection of denitrifiers and three nosZ genes from marine sediments. FEMS Microbiol. Lett. 162, 61-68. doi: 10.1016/S0378-1097(98) 00103-7

Sharma, R., Ryan, K., Hao, X., Larney, F. J., McAllister, T. A., and Topp, E. (2011). Real-time quantification of mcrA, pmoA for methanogen, methanotroph estimations during composting. J. Environ. Qual. 40, 199-205. doi: 10.2134/ jeq2010.0088

Shen, Y., Ren, L., Li, G., Chen, T., and Guo, R. (2011). Influence of aeration on $\mathrm{CH}_{4}, \mathrm{~N}_{2} \mathrm{O}$ and $\mathrm{NH}_{3}$ emissions during aerobic composting of a chicken manure and high $\mathrm{C} / \mathrm{N}$ waste mixture. Waste Manag. 31, 33-38. doi: 10.1016/j.wasman. 2010.08.019

Shrestha, M., Shrestha, P. M., Frenzel, P., and Conrad, R. (2010). Effect of nitrogen fertilization on methane oxidation, abundance, community structure, and gene expression of methanotrophs in the rice rhizosphere. ISME J. 4, 1545-1556. doi: 10.1038 /ismej.2010.89

Sonoki, T., Furukawa, T., Jindo, K., Suto, K., Aoyama, M., and Sanchez-Monedero, M. A. (2013). Influence of biochar addition on methane metabolism during thermophilic phase of composting. J. Basic Microb. 53, 617-621. doi: 10.1002/ jobm.201200096

Stein, L. Y., and Klotz, M. G. (2011). Nitrifying and denitrifying pathways of methanotrophic bacteria. Biochem. Soc. Trans. 39, 1826-1831. doi: 10.1042/ BST20110712

Steinberg, L. M., and Regan, J. M. (2009). mcrA-targeted real-time quantitative PCR method to examine methanogen communities. Appl. Environ. Microbiol. 75, 4435-4442. doi: 10.1128/AEM.02858-08

Steudler, P. A., Bowden, R. D., Melillo, J. M., and Aber, J. D. (1989). Influence of nitrogen-fertilization on methane uptake in temperate forest soils. Nature 341, 314-316. doi: 10.1038/341314a0

Tiedje, J. M. (1988). "Ecology of denitrification and of dissimilatory nitrate reduction to ammonium," in Biology of Anaerobic Microorganisms, ed. A. J. B. Zehnder (New York, NY: John Wiley and Sons, Inc), 179-244.

Tsutsui, H., Fujiwara, T., Matsukawa, K., and Funamizu, N. (2013). Nitrous oxide emission mechanisms during intermittently aerated composting of cattle manure. Bioresour. Technol. 141, 205-211. doi: 10.1016/j.biortech.2013. 02.071

Wang, C., Lu, H., Dong, D., Hui, D., Strong, P. J., Hailong, W., et al. (2013). Insight into the effects of biochar on manure composting: evidence supporting the relationship between $\mathrm{N}_{2} \mathrm{O}$ emission and denitrifying community. Environ. Sci. Technol. 47, 7341-7349. doi: 10.1021/es305293h

Wasmund, K., Kurtboke, D. I., Burns, K. A., and Bourne, D. G. (2009). Microbial diversity in sediments associated with a shallow methane seep in the tropical
Timor Sea of Australia reveals a novel aerobic methanotroph diversity. FEMS Microbiol. Ecol. 68, 142-151. doi: 10.1111/j.1574-6941.2009.00667.x

Xin, J. Y., Cui, J. R., Niu, J. Z., Hua, S. F., Xia, C. G., Li, S. B., et al. (2004). Production of methanol from methane by methanotrophic bacteria. Biocatal. Biotransformation 22, 225-229. doi: 10.1080/10242420412331283305

Xu, S., Hao, X., Standford, K., McAllister, T. A., Larney, F. J., and Wang, J. (2007). Greenhouse gas emissions during co-composting of calf mortalities with manure. J. Environ. Qual. 36, 1914-1919. doi: 10.2134/jeq2007.0080

Yoshida, M., Ishii, S., Otsuka, S., and Senoo, K. (2009). Temporal shifts in diversity and quantity of nirS and nirK in a rice paddy field soil. Soil Biol. Biochem. 41, 2044-2051. doi: 10.1016/j.soilbio.2009.07.012

Zhang, L., Zeng, G., Zhang, J., Chen, Y., Yu, M., Lu, L., et al. (2015). Response of denitrifying genes coding for nitrite (nirK or nirS) and nitrous oxide (nosZ) reductases to different physico-chemical parameters during agricultural waste composting. Appl. Microbiol. Biotechnol. 99, 4059-4070. doi: 10.1007/s00253014-6293-3

Zhou, L., Wang, Y., Long, X. E., Guo, J., and Zhu, G. (2014). High abundance and diversity of nitrite-dependent anaerobic methane-oxidizing bacteria in a paddy field profile. FEMS Microbiol. Lett. 360, 33-41. doi: 10.1111/1574-6968.12567

Zhou, Z. F., Zheng, Y. M., Shen, J. P., Zhang, L. M., and He, J. Z. (2011). Response of denitrification genes nirS, nirK and nosZ to irrigation water quality in a Chinese agricultural soil. Environ. Sci. Pollut. Res. 18, 1644-1652. doi: 10.1007/s11356011-0482-8

Zou, J., Huang, Y., Jiang, J., Zheng, X., and Sass, R. L. (2005). A 3-year field measurement of methane and nitrous oxide emissions from rice paddies in China: effects of water regime, crop residue, and fertilizer application. Global. Biogeochem. Cycl. 19, GB2012. doi: 10.1029/2004GB002401

Zou, J., Huang, Y., Qin, Y., Liu, S., Shen, Q., Pan, G., et al. (2009). Changes in fertilizer-induced direct $\mathrm{N}_{2} \mathrm{O}$ emissions from paddy fields during rice-growing season in china between 1950s and 1990s. Global Change Biol. 15, 229-242. doi: 10.1111/j.1365-2486.2008.01775.x

Conflict of Interest Statement: The authors declare that the research was conducted in the absence of any commercial or financial relationships that could be construed as a potential conflict of interest.

Copyright (C) $2017 \mathrm{Li}$, Song, Gao, Jin, Liu, Shen and Zou. This is an open-access article distributed under the terms of the Creative Commons Attribution License (CC BY). The use, distribution or reproduction in other forums is permitted, provided the original author(s) or licensor are credited and that the original publication in this journal is cited, in accordance with accepted academic practice. No use, distribution or reproduction is permitted which does not comply with these terms. 